\title{
Hydrogen Sulfide Metabolism and Pulmonary Hypertension
}

\author{
Lukas Roubenne ${ }^{1,2,3}$, Roger Marthan ${ }^{1,2,4} \mathbb{D}$, Bruno Le Grand ${ }^{3}$ and Christelle Guibert $1,2, *$ (D) \\ 1 INSERM, Centre de Recherche Cardio-Thoracique de Bordeaux, U1045, Avenue du Haut-Lévêque, \\ F-33604 Pessac, France; lukas.roubenne@u-bordeaux.fr (L.R.); Roger.marthan@u-bordeaux.fr (R.M.) \\ 2 Centre de Recherche Cardio-Thoracique de Bordeaux, Univ Bordeaux, U1045, 146 Rue Léo Saignat, \\ F-33000 Bordeaux, France \\ 3 OP2 Drugs, Avenue du Haut Lévêque, F-33604 Pessac, France; bruno@op2drugs.com \\ 4 CHU de Bordeaux, Avenue du Haut Lévêque, F-33604 Pessac, France \\ * Correspondence: christelle.guiber@@u-bordeaux.fr
}

check for

updates

Citation: Roubenne, L.; Marthan, R.; Le Grand, B.; Guibert, C. Hydrogen Sulfide Metabolism and Pulmonary Hypertension. Cells 2021, 10, 1477. https: / / doi.org/10.3390/cells10061477

Academic Editor: Rozenn Quarck

Received: 30 April 2021

Accepted: 9 June 2021

Published: 12 June 2021

Publisher's Note: MDPI stays neutral with regard to jurisdictional claims in published maps and institutional affiliations.

Copyright: (C) 2021 by the authors. Licensee MDPI, Basel, Switzerland. This article is an open access article distributed under the terms and conditions of the Creative Commons Attribution (CC BY) license (https:/ / creativecommons.org/licenses/by/ $4.0 /)$.

\begin{abstract}
Pulmonary hypertension (PH) is a severe and multifactorial disease characterized by a progressive elevation of pulmonary arterial resistance and pressure due to remodeling, inflammation, oxidative stress, and vasoreactive alterations of pulmonary arteries (PAs). Currently, the etiology of these pathological features is not clearly understood and, therefore, no curative treatment is available. Since the 1990s, hydrogen sulfide $\left(\mathrm{H}_{2} \mathrm{~S}\right)$ has been described as the third gasotransmitter with plethoric regulatory functions in cardiovascular tissues, especially in pulmonary circulation. Alteration in $\mathrm{H}_{2} \mathrm{~S}$ biogenesis has been associated with the hallmarks of $\mathrm{PH} . \mathrm{H}_{2} \mathrm{~S}$ is also involved in pulmonary vascular cell homeostasis via the regulation of hypoxia response and mitochondrial bioenergetics, which are critical phenomena affected during the development of $\mathrm{PH}$. In addition, $\mathrm{H}_{2} \mathrm{~S}$ modulates ATP-sensitive $\mathrm{K}^{+}$channel $\left(\mathrm{K}_{\text {ATP }}\right)$ activity, and is associated with PA relaxation. In vitro or in vivo $\mathrm{H}_{2} \mathrm{~S}$ supplementation exerts antioxidative and anti-inflammatory properties, and reduces PA remodeling. Altogether, current findings suggest that $\mathrm{H}_{2} \mathrm{~S}$ promotes protective effects against $\mathrm{PH}$, and could be a relevant target for a new therapeutic strategy, using attractive $\mathrm{H}_{2} \mathrm{~S}$-releasing molecules. Thus, the present review discusses the involvement and dysregulation of $\mathrm{H}_{2} \mathrm{~S}$ metabolism in pulmonary circulation pathophysiology.
\end{abstract}

Keywords: pulmonary hypertension; hydrogen sulfide; vascular remodeling; vascular reactivity; oxidative stress; inflammation

\section{Introduction}

Pulmonary hypertension $(\mathrm{PH})$ is a group of multifactorial and devastating cardiovascular conditions characterized by a progressive elevation of pulmonary arterial resistance ( $\geq 3$ Wood) and mean pulmonary artery pressure (mPAP) above $20 \mathrm{mmHg}$ [1], leading to right ventricular (RV) hypertrophy, failure, and ultimately to premature death [2,3]. $\mathrm{PH}$ is divided into five groups according to clinical, hemodynamic, and etiological characteristics, as well as treatment strategy: idiopathic and heritable pulmonary arterial hypertension (PAH) (group 1); $\mathrm{PH}$ due to left heart disease (group 2); PH due to lung diseases and/or hypoxia (group 3); $\mathrm{PH}$ associated with chronic thromboembolism (group 4); and finally, $\mathrm{PH}$ forms with unclear or multifaceted origins (group 5) [2]. PH development is associated with complex functional and structural modifications of the pulmonary arteries (PA), involving both pulmonary arterial endothelial cells (PAECs) and smooth muscle cells (PASMCs) [4]. Impairment of PA reactivity is a critical PH hallmark, and is linked to an imbalance of production and bioavailability of vasocontractile and vasorelaxant mediators $[5,6]$. This dysregulation is intimately linked to endothelial dysfunction [6,7], and is characterized by excessive constriction and decreased relaxation of PAs [5,8]. Concurrently, architectural changes of PA are mainly due to arterial wall remodeling, including media thickening of proximal arteries, intimal neo-formation, and fibrosis [4]. It is now well established that such changes are associated with PASMC and PAEC alterations during PH—namely, 
a pro-proliferative and apoptosis-resistant phenotype; an increased migration potential; extracellular matrix remodeling, mainly through excessive collagen deposition; and also endothelial-to-mesenchymal transdifferentiation $[4,9]$. Exacerbated inflammatory vascular responses also play a critical role in the development of $\mathrm{PH}$. Actually, circulating concentrations of several proinflammatory cytokines, such as interleukin 6 (IL-6) and tumor necrosis factor alpha (TNF- $\alpha$ ) [4,10], are abnormally increased in PAs regardless of the form of PH. This inflammatory context is associated with a worse clinical outcome in $\mathrm{PH}$ patients, and could contribute to exaggerated reactivity and remodeling of vascular cells. Furthermore, oxidative stress and associated enzymatic and/or mitochondrial reactive oxygen species (ROS) production are also considered to be important effectors in the development of $\mathrm{PH}$, especially during PAs' responses to hypoxia [11-13]. Currently, therapeutic strategies developed against $\mathrm{PH}$ are based on the use of a treatment targeted to reduce exacerbated pulmonary vascular contractility and remodeling, along with a more general treatment to alleviate respiratory symptoms and RV failure [2]. However, these treatments fail to cure $\mathrm{PH}$, and lung transplantation remains too often a requisite solution for eligible patients with severe forms of $\mathrm{PH}$ resistant to medical management. In the absence of suitable treatments, patients with idiopathic pulmonary arterial hypertension have a mean survival of 2.8 years [2]. As a consequence, the search for new therapeutic targets in the landscape of PH's cellular and molecular mechanisms remains essential.

Sulfur-based gases, such as hydrogen sulfide $\left(\mathrm{H}_{2} \mathrm{~S}\right)$, have been known for a long time as environmentally poisonous and malodorous gases [14]. Aside from this harmful aspect, $\mathrm{H}_{2} \mathrm{~S}$ is also involved in the regulation of several biological processes, and is currently considered to be a novel complementary gasotransmitter to the well-known nitric monoxide (NO) and carbon monoxide (CO). The growing importance of $\mathrm{H}_{2} \mathrm{~S}$ in biological research is evidenced by the substantial increase in the number of original and review articles in the PubMed database dealing with this sulfur-based gas since 1996 (Figure 1). Like NO and $\mathrm{CO}, \mathrm{H}_{2} \mathrm{~S}$ exhibits high solubility in aqueous solution and in lipids, suggesting an efficient ability to cross plasma membranes [15]. $\mathrm{H}_{2} \mathrm{~S}$ is enzymatically produced under various physiological conditions, and acts as an endogenous signaling molecule that does not require a second messenger or any receptor activation [15-18]. Cystathionine- $\beta$ synthase (CBS) and cystathionine- $\gamma$ lyase (CSE) — two pyridoxal $5^{\prime}$-phosphate (PLP)-dependent enzymes-are considered to be the main sources of $\mathrm{H}_{2} \mathrm{~S}$ in mammalian cells [19-21]. A third enzyme-3-mercaptopyruvate sulfur transferase (3-MST) - has also been shown to release $\mathrm{H}_{2} \mathrm{~S}$ along with cysteine aminotransferase (CAT) activity [21-24]. $\mathrm{H}_{2} \mathrm{~S}$ was initially described as a vasodilator, lowering blood pressure $[25,26]$ through the ATP-sensitive potassium channel $\left(\mathrm{K}_{\mathrm{ATP}}\right)$ openings in smooth muscle cells [27]. $\mathrm{H}_{2} \mathrm{~S}$ also plays a critical role in numerous cardiovascular diseases, including atherosclerosis, diabetes-associated vascular disorders, and systemic hypertension [28-32], in which alterations of endogenous sulfur homeostasis can be observed [33].

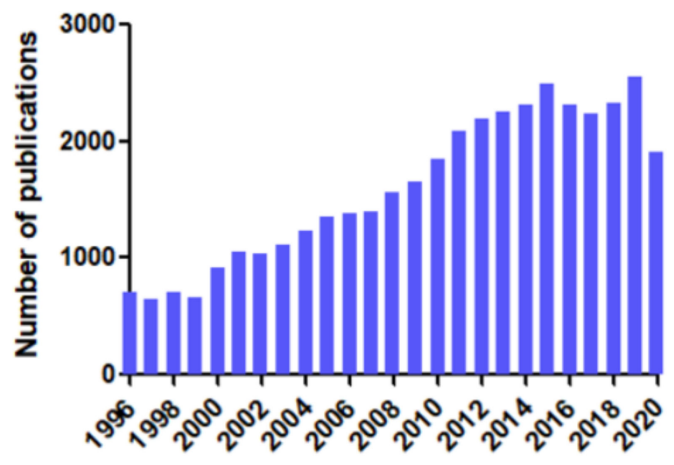

Figure 1. Rising number of publications in $\mathrm{H}_{2} \mathrm{~S}$ research fields. A search for original and review articles published from 1996 to 2020 was performed in the PubMed database (www.ncbi.nlm.nih. gov / pubmed, accessed on 10 June 2021) using the key words "hydrogen sulfide". 
In the context of the pulmonary circulation, several studies have already highlighted the essential role of endogenous $\mathrm{H}_{2} \mathrm{~S}$ metabolism in both regulating physiological functions and contributing to the pathological hallmarks of PH [34-37]. CBS, CSE, and 3-MST are expressed in the intima and media of PAs [27,38-44], where $\mathrm{H}_{2} \mathrm{~S}$ is supposed to regulate oxygen sensing and associated hypoxic pulmonary vasoconstriction (HPV) $[38,39,45,46]$. $\mathrm{H}_{2} \mathrm{~S}$ activates smooth muscle cell $\mathrm{K}_{\text {ATP }}$ channels and, thus, contributes to PA relaxation [42], possibly in synergy with NO [47]. Interestingly, in vivo PH models are associated with dysregulated plasma $\mathrm{H}_{2} \mathrm{~S}$ content and lung CSE expression [34,48-50]. Moreover, oxidative and endoplasmic reticulum (ER) stress are attenuated by exogenous $\mathrm{H}_{2} \mathrm{~S}$ supplementation in several PH models [51-53]. Such dysregulation of $\mathrm{H}_{2} \mathrm{~S}$ metabolism in various cardiovascular diseases, including $\mathrm{PH}$, leads to the consideration of new therapeutic strategies based on natural or synthetic $\mathrm{H}_{2}$ S-releasing molecules such as GYY4137, the dithiolthione family, and garlic-derived donors [26,54,55], which have already exhibited interesting effects on pulmonary circulation pathophysiology $[51,52,56,57]$. Thus, the present review focuses on recent advances in the involvement of $\mathrm{H}_{2} \mathrm{~S}$ metabolism and the dysregulation of its production in pulmonary circulation, and their consequences in the context of PH. Future prospects for the potential use of $\mathrm{H}_{2} \mathrm{~S}$ donors as new therapeutic tools are also discussed.

\section{2. $\mathrm{H}_{2} \mathrm{~S}$ Metabolism in the Pulmonary Vasculature}

$\mathrm{H}_{2} \mathrm{~S}$ is endogenously produced under physiological conditions mainly through enzymatic pathways, but several findings suggest a role of non-enzymatic pathways in $\mathrm{H}_{2} \mathrm{~S}$ mobilization [58-61]. In a physiological context, $28 \%$ of $\mathrm{H}_{2} \mathrm{~S}$ is in the undissociated form, $72 \%$ is dissociated into hydrosulfide anions $\left(\mathrm{HS}^{-}\right)$, and the rest is sulfide anions $\left(\mathrm{S}^{2-}\right)$, although in negligible amounts [62]. The effects of the undissociated and dissociated forms cannot be distinguished, and are grouped in the nomenclature $\mathrm{H}_{2} \mathrm{~S}$. Initial reports suggested that $\mathrm{H}_{2} \mathrm{~S}$ concentration was approximately $30 \mu \mathrm{M}$ in lung tissue, and rose to more than $200 \mu \mathrm{M}$ in the heart, brain, and plasma [63]. However, methodological considerations related to variability in $\mathrm{pH}$, temperature, substrates concentration, etc., suggested that these concentrations were far from physiological relevance [64]. In fact, steady-state $\mathrm{H}_{2} \mathrm{~S}$ concentration was reported to be in the nanomolar range in most tissues and in plasma $[63,64]$. This range is consistent with the fact that $\mathrm{H}_{2} \mathrm{~S}$ undergoes a high turnover rate in physiological conditions, characterized by an important production associated with rapid oxidation [64]. At high concentrations $\left(\left(\mathrm{H}_{2} \mathrm{~S}\right)>20 \mu \mathrm{M}\right), \mathrm{H}_{2} \mathrm{~S}$ triggers detrimental cellular consequences [65], characterized by mitochondrial poisoning due to inhibition of cytochrome c oxidase (complex IV) $[33,66,67]$. Thus, the duality of $\mathrm{H}_{2} \mathrm{~S}$ 's effects requires a fine regulation of the production/clearance balance.

\subsection{Anabolic Pathways of $\mathrm{H}_{2} \mathrm{~S}$}

In mammalian cells, $\mathrm{H}_{2} \mathrm{~S}$ is primarily produced through the action of specific enzymes involved in homocysteine metabolism and L-cysteine catabolism: CSE, CBS, and 3-MST/CAT coupling. CSE was initially predominantly found in cardiovascular tissues, with marked expression in the heart and vessels $[15,28]$. CBS is mainly present in brain cells and the central nervous system although anterior reports suggest that when homocysteine levels are high, $\mathrm{H}_{2} \mathrm{~S}$ can be produced by CBS in endothelial cells [21,68]. A more recent study demonstrated that the loss of CBS in endothelial cells decrease $\mathrm{H}_{2} \mathrm{~S}$ production by $50 \%$ and dysregulates endothelial signaling [68]. CSE and CBS are two PLP-dependent enzymes mainly localized in the cytosol. Interestingly, several reports showed a possible translocation of CSE and CBS into mitochondria under cellular stress conditions [69,70]. In vascular smooth muscle cells, translocation of CSE from the cytosol to the mitochondria is induced by cytosolic calcium increase and, thus, promotes $\mathrm{H}_{2} \mathrm{~S}$ production within the mitochondria, where L-cysteine concentration is three times higher than in cytosol [70]. Likewise, CBS is transferred into the mitochondria in response to hypoxia [69]. CSE and CBS have been considered for a long time to be the main endogenous $\mathrm{H}_{2} \mathrm{~S}$ enzymatic sources in cells [19-21] by acting on L-cysteine, their predominant substrate. L-cysteine is 
a sulfhydryl amino acid derived from nutrition or endogenously generated from homocysteine via the canonical transsulfuration pathway, involving CSE and CBS (Figure 2a). Briefly, CBS converts homocysteine and L-serine into cystathionine, which is then metabolized by CSE in L-cysteine and $\alpha$-ketobutyrate [71]. To generate $\mathrm{H}_{2} \mathrm{~S}$ from L-cysteine, CSE and CBS catalyze a desulfhydration reaction and generate pyruvate and L-serine, respectively. Under physiological conditions, intracellular L-cysteine amounts exceed those of homocysteine, suggesting that L-cysteine desulfhydration is the main pathway of CSEassociated $\mathrm{H}_{2} \mathrm{~S}$ production. However, in hyperhomocysteinemia, CSE can catalyze $\mathrm{H}_{2} \mathrm{~S}$ release from two molecules of homocysteine [21,71], suggesting that the latter constitutes an alternative substrate for $\mathrm{H}_{2} \mathrm{~S}$ production. It should be noted that $\mathrm{H}_{2} \mathrm{~S}$ production by CBS is more efficient when homocysteine acts as a co-substrate of L-cysteine [71]. CBS was also shown to be allosterically activated and stabilized by S-adenosyl-L-methionine-a methyl group donor [71]. On the other hand, CO and NO inhibit CBS activity, highlighting gasotransmitter crosstalk [71]. CSE expression is upregulated by multiple factors-namely, ROS [72], ER stress [73], and calcium increase [74,75]. CSE transcription is also upregulated by the action of TNF- $\alpha$ during inflammation [76]. CSE activity is enhanced by calmodulin in the presence of high calcium concentrations [28], although this finding remains controversial [71]. Contrary to CBS, CSE expression and activity are stimulated by NO in vascular tissues using NO donors [27].

PLP-independent 3-MST localization in tissue was initially mentioned in brain tissue [23], and later in liver, large intestine, and kidney tissues [77]. However, 3-MST is also expressed in the endothelium and media of the thoracic aorta [22]. Cytosolic CAT1 and mitochondrial CAT2 are widely expressed in liver, heart, and kidney tissues [78]. CAT1/2 were also detected in the thoracic aorta, but only in endothelial cells [22], leading to a proposed endothelial predominance of $\mathrm{H}_{2} \mathrm{~S}$ production by CAT/3-MST coupling. 3-MST is mainly present within the mitochondrial matrix, but is also detectable in the cytosol [66,79]. To produce $\mathrm{H}_{2} \mathrm{~S}$, 3-MST requires the activity of CAT, which exists in two forms: CAT1 and CAT2 localized in the cytosol and the mitochondria, respectively [21]. Indeed, CAT activity catalyzes transamination between L-cysteine and $\alpha$-ketoglutarate in order to produce 3-mercatopyruvate. The latter is then used as a substrate by 3-MST to release $\mathrm{H}_{2} \mathrm{~S}$ in presence of reducing molecules, such as endogenous thioredoxin (Trx) or dihydrolipoic acid (DHLA) [21-24]. Trx is a class of ubiquitously expressed redox proteins, including cytosolic Trx1 and mitochondrial Trx2 [24]. DHLA is a reducing compound present in the mitochondria [24]. Although 3-MST-associated $\mathrm{H}_{2} \mathrm{~S}$ release occurs in the cytosol and the mitochondria, the steady-state contribution of mitochondrial and cytosolic 3-MST to cellular $\mathrm{H}_{2} \mathrm{~S}$ production remains to be determined. Due to its predominant mitochondrial localization, $\mathrm{H}_{2} \mathrm{~S}$ production by 3-MST contributes to mitochondrial metabolism through oxidation by sulfide quinone oxidoreductase (SQR), which is part of the mitochondrial electron transport chain (ETC) [80] (Figure 2b). 3-MST expression is also enhanced in human umbilical vein endothelial cells in response to shear flow [81]. In contrast, 3-MST activity can be inhibited by oxidative stress through redox modifications of its molecular structure [82].

Recent advances in endogenous $\mathrm{H}_{2} \mathrm{~S}$ metabolism study suggest that $\mathrm{H}_{2} \mathrm{~S}$ can be generated independently of CSE, CBS, and 3-MST/CAT coupling. Although minor, nonenzymatic $\mathrm{H}_{2} \mathrm{~S}$ release occurs during the chemical reduction of reactive sulfur groups in thiosulfates or polysulfides (Figure 2a). Indeed, Benavides et al. demonstrated that dietary garlic (Allium sativum)-derived organic polysulfides (diallyl disulfide and diallyl trisulfide) can release $\mathrm{H}_{2} \mathrm{~S}$ in presence of GSH and glucose metabolism [58]. In addition to being a substrate for $\mathrm{H}_{2} \mathrm{~S}$-generating enzymes, L-cysteine also generates $\mathrm{H}_{2} \mathrm{~S}$ in physiological conditions in blood, in the presence of iron and vitamin B6 [59]. As a consequence, it has been suggested that basal circulating $\mathrm{H}_{2} \mathrm{~S}$ content is due to this novel non-enzymatic process. 


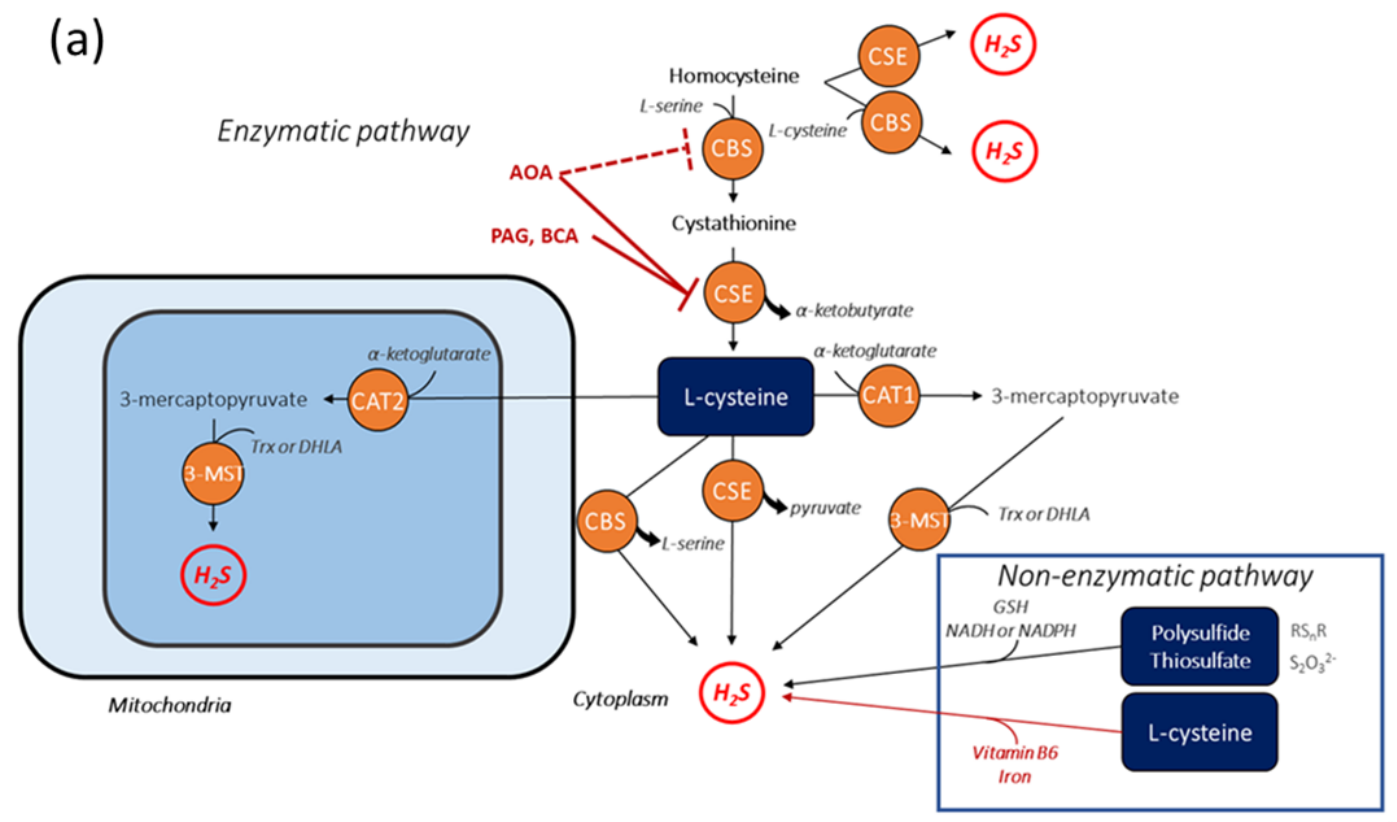

(b)

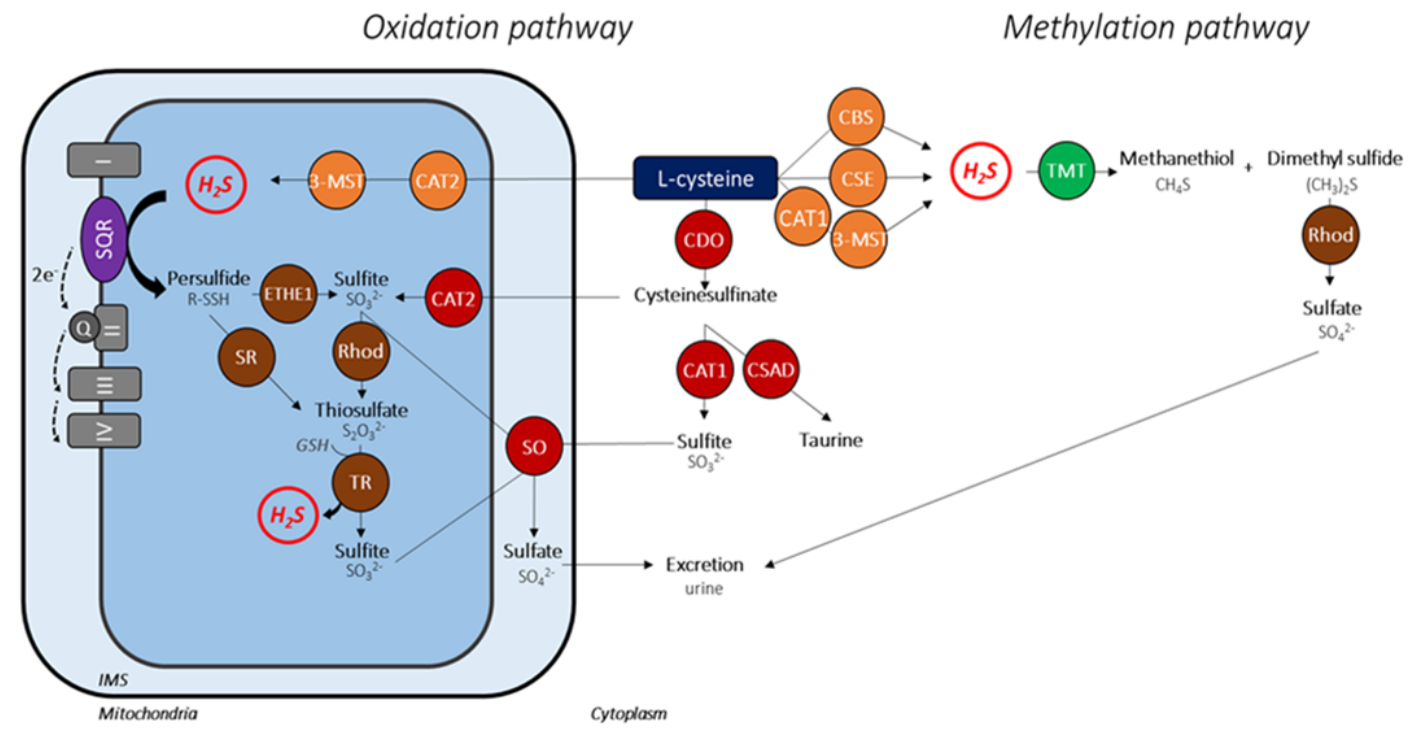

Figure 2. Main $\mathrm{H}_{2} \mathrm{~S}$ anabolic and catabolic pathways in mammalian cells. (a) Endogenous hydrogen sulfide $\left(\mathrm{H}_{2} \mathrm{~S}\right)$ production is mainly due to enzymatic pathways through the activity of cystathionine $\gamma$-lyase (CSE), cystathionine $\beta$-synthase (CBS), and 3-mercaptopyruvate sulfur transferase/cysteine aminotransferase (3-MST/CAT) coupling. Cytosolic CBS and CSE are involved in the interconversion of homocysteine to L-cysteine (transsulfuration pathway). In the context of cysteine catabolism, CBS and CSE desulfhydrate L-cysteine (and homocysteine) to produce $\mathrm{H}_{2} \mathrm{~S}$. L-cysteine can also act as a substrate with $\alpha$-ketoglutarate to produce 3-mercaptopyruvate through a transamination reaction via activity of the CAT1 and CAT2 enzymes (cytosolic and mitochondrial, respectively). CSE activity is selectively inhibited by DL-propargylglycine (PAG) and $\beta$-cyanoalanine (BCA). CBS and CSE activities-especially the latter-are both inhibited by AOA. In a reducing environment (presence of thioredoxin (Trx) and dihydrolipoic acid (DHLA)—two endogenous reducing molecules), 3-mercaptopyruvate is then used by 3-MST to release pyruvate and $\mathrm{H}_{2} \mathrm{~S}$, mainly in the mitochondria. To a lesser extent, non-enzymatic $\mathrm{H}_{2} \mathrm{~S}$ production can occur in physiological conditions, caused by reactive sulfur groups of thiosulfates $\left(\mathrm{S}_{2} \mathrm{O}_{3}{ }^{2-}\right)$ or polysulfides $\left(\mathrm{RS}_{\mathrm{n}} \mathrm{S}\right)$ in the presence of glutathione (GSH) or reducing equivalents (nicotinamide adenine dinucleotide (NADH) and nicotinamide adenine dinucleotide phosphate (NADPH)). (b) Oxidation, the major catabolic pathway to maintaining $\mathrm{H}_{2} \mathrm{~S}$ homeostasis, occurs in the mitochondria. $\mathrm{H}_{2} \mathrm{~S}$ is rapidly oxidized by sulfide quinone oxidoreductase (SQR) to form persulfides (R-SSH), which undergo another oxidation step by persulfide dioxygenase (ETHE1) to produce sulfites $\left(\mathrm{SO}_{3}{ }^{2-}\right)$. 
In this process, two electrons $\left(\mathrm{e}^{-}\right)$are released to ubiquinone $(\mathrm{Q})$ and transferred to complex III of the mitochondrial electron transfer chain (ETC) $[33,83]$. Sulfites are either converted to thiosulfates or directly to sulfates $\left(\mathrm{SO}_{4}{ }^{2-}\right)$, thanks to rhodanese (Rhod) and sulfite oxidase (SO), respectively. The final catabolic products-sulfates-are finally excreted via urine. In an additional pathway, persulfides can be degraded to thiosulfates by sulfur transferase (SR). Thiosulfates can also be converted to sulfites and $\mathrm{H}_{2} \mathrm{~S}$ by thiosulfate reductase (TR) in the presence of GSH, which, ultimately, leads to sulfate production by SO. $\mathrm{H}_{2} \mathrm{~S}$ methylation is the other, although minor, clearance pathway. $\mathrm{H}_{2} \mathrm{~S}$ is first converted to methanethiol $\left(\mathrm{CH}_{4} \mathrm{~S}\right)$ and dimethyl sulfide $\left(\left(\mathrm{CH}_{3}\right)_{2} \mathrm{~S}\right)$ via S-methyltransferase (TMT) activity. Then, Rhod breaks down dimethyl sulfide into sulfates, which are then excreted through urine. L-cysteine is degraded to cysteine sulfinate by cysteine dioxygenase (CDO) activity. Cysteine sulfinate is then converted to sulfites by CAT1/2 and, ultimately, to sulfate by SO, or to taurine by cysteine sulfinate decarboxylase (CSAD). 3-MST: 3-mercaptopyruvate sulfur transferase; AOA: aminooxyacetate; BCA: $\beta$-cyanoalanine; CAT1/2: cysteine aminotransferase 1/2; CBS: cystathionine $\beta$-synthase; CDO: cysteine dioxygenase; CSE: cystathionine $\gamma$-lyase; CSAD: cysteine sulfinate decarboxylase; DHLA: dihydrolipoic acid; $\mathrm{e}^{-}$: electron; ETC: electron transfer chain; I, II, III, and IV: mitochondria complexes I-IV of ETC; ETHE1: persulfide dioxygenase; GSH: glutathione; $\mathrm{H}_{2} \mathrm{~S}$ : hydrogen sulfide; IMS: intermembrane space; NADH: nicotinamide adenine dinucleotide; NADPH: nicotinamide adenine dinucleotide phosphate; PAG: DL-propargylglycine; Q: ubiquinone; Rhod: rhodanese; SO: sulfite oxidase; SQR: sulfide quinone oxidoreductase; SR: sulfur transferase; TMT: S-methyltransferase; TR: thiosulfate reductase; Trx: thioredoxin.

\subsection{Catabolic Pathways of $\mathrm{H}_{2} \mathrm{~S}$}

Control of $\mathrm{H}_{2} \mathrm{~S}$ metabolism requires an efficient clearance in order to avoid its detrimental effects on mitochondrial function [66]. Indeed, at high concentrations, $\mathrm{H}_{2} \mathrm{~S}$ inhibits oxygen binding to mitochondrial complex IV, leading to ETC inhibition and the reduction of mitochondrial energetic production $[33,66] . \mathrm{H}_{2} \mathrm{~S}$ catabolism mainly occurs in the mitochondria through oxidation pathways (Figure 2b). From an evolutionary point of view, such mitochondrial location for $\mathrm{H}_{2} \mathrm{~S}$ oxidation is unsurprising, owing to the primitive origin of this organelle (a sulfide-oxidizing bacterium). $\mathrm{H}_{2} \mathrm{~S}$ clearance begins with its oxidation in the mitochondrial matrix by SQR, producing persulfide (R-SSH), and may occur in all cellular types (Figure 2b) [71]. In physiological steady-state conditions, SQR actively participates in electron transfer to ubiquinone. However, in the oxidation process, $\mathrm{H}_{2} \mathrm{~S}$ can donate electrons via $\mathrm{SQR}$, which then follow the traditional transfer route to complexes III and IV and stimulate energetic metabolism [83]. Persulfides are then oxidized by persulfide dioxygenase (ETHE1) to generate sulfites $\left(\mathrm{SO}_{3}{ }^{2-}\right)$. Sulfites are further oxidized by sulfite oxidase (SO) to sulfates $\left(\mathrm{SO}_{4}{ }^{2-}\right)$, or by rhodanese (Rhod) to thiosulfates $\left(\mathrm{S}_{2} \mathrm{O}_{3}{ }^{2-}\right)$, which can also be reduced to sulfites and $\mathrm{H}_{2} \mathrm{~S}$ by thiosulfate reductase (TR) in presence of GSH [84]. The terminal catabolic products of $\mathrm{H}_{2} \mathrm{~S}$ - sulfates-are finally eliminated in urine. Additionally, persulfides generated by SQR can also be directly converted to thiosulfates by sulfur transferase (SR) [84]. In physiological conditions, $\mathrm{H}_{2} \mathrm{~S}$ oxidation is very fast and efficient, maintaining a low level of $\mathrm{H}_{2} \mathrm{~S}$ in tissues (i.e., half-lives of 2.0, 2.8, and $10.0 \mathrm{~min}$ in liver, kidney, and brain tissues, respectively) [64]. However, in hypoxic conditions, $\mathrm{H}_{2} \mathrm{~S}$ oxidation decreases and $\mathrm{H}_{2} \mathrm{~S}$ concentration logically increases, suggesting that $\mathrm{H}_{2} \mathrm{~S}$ could be an efficient oxygen sensor [85].

Although considered to be minor, and much slower than oxidation, methylation of $\mathrm{H}_{2} \mathrm{~S}$ also allows $\mathrm{H}_{2} \mathrm{~S}$ elimination (Figure $2 \mathrm{~b}$ ). In the cytoplasm, ubiquitous $\mathrm{S}$-methyltransferase (TMT) converts $\mathrm{H}_{2} \mathrm{~S}$ to methanethiol $\left(\mathrm{CH}_{4} \mathrm{~S}\right)$ and dimethyl sulfide $\left(\left(\mathrm{CH}_{3}\right)_{2} \mathrm{~S}\right)$. The latter is then oxidized by Rhod to sulfates, which are excreted via urine [15].

In addition to enzymatic routes, $\mathrm{H}_{2} \mathrm{~S}$ can also be eliminated through expiration. Detection of exhaled $\mathrm{H}_{2} \mathrm{~S}$ is possible when large amounts are present, such as during sodium sulfide administration [86]. $\mathrm{H}_{2} \mathrm{~S}$ concentration in exhaled air is altered in various hypoxic diseases, such as chronic obstructive pulmonary disease (COPD) or asthma [87]. However, there is no standardized method to quantify this parameter, and very few data regarding $\mathrm{H}_{2} \mathrm{~S}$ expiration in healthy population are available [88].

Likewise, intracellular L-cysteine concentration is tightly regulated, especially via oxidative pathways. Briefly, when it is excessive, the enzyme cysteine dioxygenase (CDO) oxidizes L-cysteine to cysteine sulfinate (Figure 2b) [89]. The latter is further converted to 
sulfites thanks to the activity of cytosolic and mitochondrial CAT and SO, respectively, or to taurine by cysteine sulfinate decarboxylase (CSAD) [89].

\section{3. $\mathrm{H}_{2} \mathrm{~S}$ in the Pulmonary Circulation}

Hosoki et al. first characterized CSE as the major source of $\mathrm{H}_{2} \mathrm{~S}$ in vascular tissues [25]. CSE is abundantly expressed in bovine [38,39], broiler [40], and rat [27,41-44] PAs. CSE expression was detected in pulmonary vessels early during post-natal lung development in mice [90]. Discrepancies in the localization of CSE expression were reported in the PA walls. Some studies mentioned that PA media and associated smooth muscle cells are the main or even exclusive sites of CSE expression in pulmonary circulation. Indeed, immunohistochemical staining showed that the presence of CSE proteins was limited to the media of rat peripheral lung vascular tissues [41], and was also found in cultured bovine PASMCs [39]. These findings are in accordance with other reports pointing out the expression of CSE in the smooth muscle cells of systemic vascular walls $[22,25,27]$. However, localization of CSE expression in the endothelium must be considered, because CSE was also detected in the endothelial layer of PAs and primary PAECs from rats [34,42,91-93]. Those discrepancies in CSE localization within the PA walls could be explained by interspecies diversity of the studied models, as well as the pulmonary arterial segments considered (proximal versus distal) $[18,45]$. As a consequence, a dual role of CSE-associated $\mathrm{H}_{2} \mathrm{~S}$ production in the media and intima of PAs should be considered.

Regarding CBS, interestingly, CBS mRNAs and proteins were also detected in rat $[42,44]$, broiler [40], and adult mouse [91] PAs. Like CSE, CBS expression was observed in pulmonary vessels during post-natal lung development in mice [90]. CBS protein quantities in rat aortic and PA tissues were similar under physiological conditions [42]. However, unlike CSE, CBS proteins were clearly detected in the endothelial cells [94] — but not in the smooth muscle cells-of bovine PAs [39]. This endothelial predominance of CBS expression is in accordance with the first report of Zhao et al., showing the absence of CBS mRNA in endothelium-free rat PAs [27]. Although CBS $\mathrm{mRNA}$ and protein expression were lower than those of CSE in rat PAs [40], the CBS inhibitor aminooxyacetate (AOA) significantly altered $\mathrm{H}_{2} \mathrm{~S}$ production [38]. In contrast, inhibition of CSE provided conflicting reports. shRNA-mediated CSE knockdown in rat PAECs significantly decreased $\mathrm{H}_{2} \mathrm{~S}$ levels in supernatants [34], whereas DL-propargylglycine (PAG)—a presumed CSE inhibitor-did not inhibit $\mathrm{H}_{2} \mathrm{~S}$ production of bovine PA homogenates in the presence of L-cysteine and pyridoxal-5'-phosphate. However, the selectivity of these commonly used pharmacological inhibitors to assess the functional involvement of CSE and CBS in a vascular context remains questionable [95]. Indeed, the selective CBS inhibitor AOA alters both CBS and CSE activity, and is even more efficient than PAG in reducing CSE activity. Altogether, CSE and CBS appear to be involved in endogenous $\mathrm{H}_{2} \mathrm{~S}$ production in the pulmonary vasculature, even though the spatial distribution of $\mathrm{H}_{2} \mathrm{~S}$ synthesis within arterial wall layers along the pulmonary vasculature remains to be clarified.

Regarding the final enzymatic source, 3-MST mRNA was observed in rat intrapulmonary arteries [43], and 3-MST proteins were detected in various human endothelial cell lines, including PAECs [18]. Immunohistochemical studies from another report indicate that 3-MST proteins are present in both endothelial and smooth muscle cells of small rat PAs [44] whereas less immunoreactivity was noticed in the media and adventitia compared to the endothelial layers of cow and sea lion PAs [39]. This broad distribution of 3-MST was also found in cultured bovine PAECs and PASMCs [39]. Interestingly, in comparison to aortic tissues, a higher 3-MST mRNA expression was quantified in PAs [42]. Cytosolic and mitochondrial CAT (CAT1 and CAT2, respectively) were notably detected in lung and systemic vascular tissues [22,44,96-98]. Du et al. firstly indicated CAT1 and CAT2 mRNA presence in rat PAs [96]. Subsequently, CAT1 and CAT2 proteins were found to be expressed in cultured PAECs, PASMCs, and fibroblasts from rat PAs $[34,99,100]$, suggesting a broad distribution within the pulmonary vascular wall. So far, few studies investigated the physiological relevance of CAT activity in $\mathrm{H}_{2} \mathrm{~S}$ synthesis in the pulmonary vascula- 
ture. Madden et al. suggested an involvement of CAT activity in the generation of $\mathrm{H}_{2} \mathrm{~S}$ through the CAT-3-MST pathway during acute hypoxic treatment of small rat PAs in the presence of cysteine and $\alpha$-ketoglutarate [45]. However, CAT/3-MST coupling cannot be considered to be a direct $\mathrm{H}_{2} \mathrm{~S}$-producing pathway, because of the requirement of reducing molecules-such as endogenous Trx or DHLA-to produce free forms of $\mathrm{H}_{2} \mathrm{~S}$ [22-24]. Cytosolic and mitochondrial Trx 1 and 2 were detected in endothelial and smooth muscle cells from human PAs [101,102]. However, the link between Trx and CAT-3-MST-associated $\mathrm{H}_{2} \mathrm{~S}$ production remains to be elucidated in pulmonary circulation.

Finally, $\mathrm{H}_{2} \mathrm{~S}$ biogenesis indirectly depends on the level of its main precursor, $\mathrm{L}$-cysteine, which, in turn, depends on the activity of $\mathrm{CDO}$ [78]. CDO was found to be greatly expressed and active in liver and kidney tissues, but also in lung tissues [84,97], and CDO proteins were also detected in the media of rat PAs [97].

\section{The Physiological Role of $\mathbf{H}_{2} \mathrm{~S}$ in Pulmonary Circulation}

\subsection{The Role of $\mathrm{H}_{2} \mathrm{~S}$ in Lung and Pulmonary Circulation Development}

In recent decades, the role of $\mathrm{H}_{2} \mathrm{~S}$ in the modulation of respiratory rhythm and the function of epithelial and mucociliary clearance has been demonstrated [87]. Moreover, $\mathrm{H}_{2} \mathrm{~S}$ is also a critical actor in lung development, including pulmonary circulation. The main $\mathrm{H}_{2} \mathrm{~S}$-producing enzymes-CBS and CSE-can be found in airway epithelial and pulmonary vessels from the early stages of post-natal development in mice [90]. Indeed, CBS and CSE are dynamically modulated during the first 10 days of mice's lives-a pivotal period for lung alveolarization. Firstly, genetic ablation of these two enzymes significantly increases small and medium PA muscularization in neonate mice. Secondly, CBS and CSE are involved in pulmonary vascular growth, since their absence decreases CD31 (endothelial cells marker) expression in newborn mice's lung homogenates. These results were confirmed by treatments with CBS siRNA or PAG, which induced a reduction in the length of tubes formed by human PAECs. GYY4137, a slow-releasing $\mathrm{H}_{2} \mathrm{~S}$ donor, also showed a promoting influence on vascular growth. Altogether, $\mathrm{H}_{2} \mathrm{~S}$ and both CBS and CSE activities seem to be important for the modulation of pulmonary vessels' architecture (Figure 3).

3-MST is also primarily expressed in the smooth muscle cells and weakly in the endothelial cells of pulmonary vessels during the lung development of young mice [103]. Nevertheless, genetic deletion of 3-MST does not trigger any structural alteration, suggesting that, unlike CBS and CSE, its presence is not required for normal lung development [103]. Overall, these findings suggest that $\mathrm{H}_{2} \mathrm{~S}$ could be a relevant target to treat pulmonary development diseases, such as bronchopulmonary dysplasia (BPD) and associated $\mathrm{PH}$ (BPD-PH), which will be discussed in Section 4.2.

\subsection{The Role of $\mathrm{H}_{2} \mathrm{~S}$ in Oxygen Sensing and Hypoxic Pulmonary Vasocontriction}

$\mathrm{H}_{2} \mathrm{~S}$ and oxygen have been linked for a long time in the history of the evolution of life on Earth. Primitive bacteria initially used sulfides from hydrothermal vents as a source of energy. The rise of the atmospheric oxygen fraction forced eukaryotic organisms to shift to oxidative metabolism, with oxygen as the final acceptor of mitochondrial ETC [85]. Interestingly, CBS's molecular structure exhibits a prosthetic heme group, which can interact with oxygen molecules according to oxygen partial pressure [69]. Teng et al. demonstrated the mitochondrial accumulation of CBS induced by ischemia/reperfusion or hypoxia challenges [69]. Under ischemic/hypoxic conditions, the decrease of CBS's oxygenation status modulates its interactions, resulting in alteration of its degradation by Lon protease, and subsequently in $\mathrm{H}_{2} \mathrm{~S}$ production in the mitochondria [69]. In the vascular sphere, hypoxia $\left(10 \% \mathrm{O}_{2}\right)$ firstly increases 3-MST protein expression, and secondly its mRNA levels, suggesting a dual regulation of 3-MST under low oxygen levels [104]. More importantly, 3-MST-associated $\mathrm{H}_{2} \mathrm{~S}$ production was involved in the hypoxia-induced migration of human umbilical endothelial cells [104]. These elements highlight the multifaceted inter- 
actions between $\mathrm{H}_{2} \mathrm{~S}$ and oxygen with a transcriptional and a putative post-transcriptional regulation of $\mathrm{H}_{2} \mathrm{~S}$-producing enzymes.

In contrast to the hypoxic systemic vasodilation, pulmonary circulation responds to hypoxia by a contraction — a so-called "hypoxic pulmonary vasoconstriction" (HPV)—which is a physiological response to drive the distribution of pulmonary capillary blood flow to areas of the lungs with high oxygen availability, in order to maintain correct hematosis. HPV is characterized by biphasic vasoconstriction constituted firstly by a transient contraction, followed by transient relaxation and then a sustained contraction [105]. The identity of the oxygen sensor(s) involved in this critical physiological mechanism remains controversial. Endothelium-free precapillary vessels do constrict in response to hypoxia, demonstrating that sensor(s), transductor(s) and effector(s), are present in the PA walls [106]. Nevertheless, the role of the endothelium should not be neglected. Indeed, PAECs modulate HPV under conditions of sustained hypoxia [107]. ROS produced in the mitochondria by the oxygendependent ETC may be critical for HPV, although two opposing hypotheses (decrease or increase of ROS production in PAs during hypoxia, reviewed in [107]) are under discussion, and the question about the potential role of other cellular actors in HPV remains open.

Olson et al. initially hypothesized that hypoxia decreases $\mathrm{H}_{2} \mathrm{~S}$ oxidation by SQR in the mitochondria via the attenuation of oxygen-dependent ETC function and, logically, increases $\mathrm{H}_{2} \mathrm{~S}$ concentration [85]. Then, the coupling of $\mathrm{H}_{2} \mathrm{~S}$ clearance and ETC function in the mitochondria could define $\mathrm{H}_{2} \mathrm{~S}$ as a putative oxygen sensor. In this framework, the elevation of the partial pressure of oxygen promotes $\mathrm{H}_{2} \mathrm{~S}$ consumption (i.e., $\mathrm{H}_{2} \mathrm{~S}$ oxidation) in bovine lung homogenates and PASMCs, with half maximal consumption at a $\mathrm{pO}_{2}$ of 3.2 and $6 \mathrm{mmHg}$, respectively [39]. Beyond reduced $\mathrm{H}_{2} \mathrm{~S}$ oxidation by SQR, hypoxia may inhibit ETHE1 activity, which requires oxygen, to oxidize persulfides to sulfites [85], but this hypothesis has not yet been validated in pulmonary circulation. Interestingly, $\mathrm{H}_{2} \mathrm{~S}$ production seems to be modulated by oxygen levels since, in rat lung homogenates and small PAs, $\mathrm{H}_{2} \mathrm{~S}$ was produced, in the presence of L-cysteine and $\alpha$-ketoglutarate, under marked hypoxic conditions, but decreased when the oxygen concentration raised [45]. Progressive increase of $\mathrm{H}_{2} \mathrm{~S}$ levels was also observed in bovine PASMCs undergoing 24 $h$ of low oxygen, suggesting that this relationship between $\mathrm{H}_{2} \mathrm{~S}$ and oxygen could occur for sustained hypoxic challenges [46]. The elevation of $\mathrm{H}_{2} \mathrm{~S}$ production under hypoxia could be explained by the mitochondrial reduction status, where the concentration of endogenous reducing molecules such as DHLA increases, triggering the release of $\mathrm{H}_{2} \mathrm{~S}$ in the mitochondria from the catabolic intermediary, thiosulfates [60]. This production is quicker than enzymatic $\mathrm{H}_{2} \mathrm{~S}$ production from L-cysteine in response to hypoxia, and could thus be an initial event in oxygen sensing [60]. Hypoxia-induced translocation of CBS and CSE to the mitochondria $[69,70]$ may also participate in increased $\mathrm{H}_{2} \mathrm{~S}$ production, but no evidence has been shown at this time in pulmonary circulation. Altogether, these reports confirm the elegant theory of $\mathrm{H}_{2} \mathrm{~S}$ and oxygen coupling, and may involve a dual regulation of $\mathrm{H}_{2} \mathrm{~S}$ production and clearance balance in the mitochondria according to the partial pressure of oxygen (Figure 3). The link between $\mathrm{H}_{2} \mathrm{~S}$ and oxygen is undeniable in pulmonary circulation $[39,45,46]$, and was indicated in other systems, such as cardiomyocytes or carotid bodies [83]. Mechanisms underlying the regulation of $\mathrm{H}_{2} \mathrm{~S}$ metabolism by oxygen partial pressure are still unclear, and require further experimentation, especially in pulmonary circulation.

To study the relationship between $\mathrm{H}_{2} \mathrm{~S}$ and $\mathrm{HPV}$, the comparison of the acute effects of $\mathrm{H}_{2} \mathrm{~S}$ and hypoxia $\left(\mathrm{pO}_{2}<5 \mathrm{mmHg}\right.$ ) on the vascular responses of pulmonary vessels from various species was assessed using $\mathrm{H}_{2} \mathrm{~S}$-releasing sulfide salts-sodium hydrosulfide (NaHS), or sodium sulfide $\left(\mathrm{Na}_{2} \mathrm{~S}\right)(1 \mathrm{mM})$-and indicated an intriguing similarity between contractile responses to $\mathrm{H}_{2} \mathrm{~S}$ and hypoxia, especially in rat PAs [38]. Surprisingly, $\mathrm{H}_{2} \mathrm{~S}$ or hypoxia triggered a biphasic response with a transient contraction (Phase 1-Ph1), followed by a transient relaxation and then a sustained contraction (phase 2-Ph2) in rat PAs. These results are consistent with recent work indicating that high concentrations $(>100 \mu \mathrm{M})$ of $\mathrm{Na}_{2} \mathrm{~S}$ induce a biphasic contraction of rat PAs, confirming a similar pattern to that observed 
in HPV [108]. To clarify the role of endogenous $\mathrm{H}_{2} \mathrm{~S}$ production in HPV, $\beta$-cyanoalanine (BCA) - a potent CSE inhibitor-reduces Ph1 contraction and subsequent relaxation of rat PAs preconstricted with norepinephrine [38]. In addition, PAG, but not AOA, decreased the rise of PA pressure in response to hypoxia in rat perfused lung tissue [45]. Knowing the importance of a reducing environment in $\mathrm{H}_{2} \mathrm{~S}$ release by mitochondrial thiosulfates, DTT and DHLA increased the amplitude of HPV in bovine PAs [60]. Interestingly, in contrast to the above results, a report by Prieto-Lloret et al. demonstrated that HPV is not inhibited by PAG when supplemented with physiological concentrations of $\mathrm{H}_{2} \mathrm{~S}$ precursors [43]. This is consistent with the absence of the effect of CSE genetic deletion on hypoxia-induced elevation of pressure in murine perfused lung tissue [109]. Another discordant point is that the incubation of PAs with DTT does not potentiate, but rather reduces, the amplitude of HPV [43]. These results put initial reports on the role of $\mathrm{H}_{2} \mathrm{~S}$ in HPV into perspective, and suggest that this process is not dependent on $\mathrm{H}_{2} \mathrm{~S}$ production in PAs (depending on either the CSE pathway or $\mathrm{H}_{2} \mathrm{~S}$ release from thiosulfates in a reducing environment). The observed similarity between PA contraction patterns triggered by either exogenous application of $\mathrm{H}_{2} \mathrm{~S}$ or hypoxia does not necessarily entail a physiological relationship (direct or indirect), although it could be explained by shared common mechanisms. Mitochondrial ROS production is a key event in HPV, and activates calcium release from the sarcoplasmic reticulum, and subsequent contraction of PAs $[107,110]$. In a recent study, Prieto-Lloret et al. assessed the mechanistic issue of biphasic $\mathrm{H}_{2} \mathrm{~S}$-induced contraction [108]. Ph1 and Ph2 contraction and relaxation caused by $\mathrm{H}_{2} \mathrm{~S}$ were not affected by L-NAME or endothelium denudation, suggesting that $\mathrm{H}_{2} \mathrm{~S}(30-1000 \mu \mathrm{M})$ acts directly on PASMCs. $\mathrm{H}_{2} \mathrm{~S}$ treatment of PASMCs increased ROS production, whereas SQR genetic deletion abolished this effect. The sustained $\mathrm{Ph} 2$ contraction was inhibited by myxothiazol (a complex III inhibitor), but not by rotenone (a complex I inhibitor). This report thus suggests that $\mathrm{H}_{2} \mathrm{~S}$ stimulates the ETC through $\mathrm{H}_{2} \mathrm{~S}$ oxidation by $\mathrm{SQR}$, in turn stimulating ROS production from complex $\mathrm{III}$ and, thus, triggering the sustained $\mathrm{Ph} 2$ contraction. In contrast, this $\mathrm{Ph} 2$ sustained contraction induced by hypoxia during HPV is inhibited by rotenone [110], thus suggesting a different mechanism from that triggered by $\mathrm{H}_{2} \mathrm{~S}$. One hypothesis is that, when the intracellular $\mathrm{H}_{2} \mathrm{~S}$ level increases, its poisoning effect on complex IV inhibits the ETC and decreases ROS production, thus inducing a transient relaxation. $\mathrm{H}_{2} \mathrm{~S}$ evaporation decreases its level and again promotes the ETC via SQR oxidation, increasing ROS production by complex III (sustained $\mathrm{Ph} 2$ contraction). Overall, $\mathrm{H}_{2} \mathrm{~S}^{\prime}$ s influence on PA contraction may be due to a balance between its promoting and blocking effects on ETC function (Figure 3).

Initial reports indicated opposite dose-dependent effects of $\mathrm{H}_{2} \mathrm{~S}$ on preconstricted bovine PAs [38]. Between $10 \mathrm{nM}$ and $10 \mu \mathrm{M}, \mathrm{H}_{2} \mathrm{~S}$ relaxes, whereas above $10 \mu \mathrm{M}$ of $\mathrm{H}_{2} \mathrm{~S}$ induces a constriction of bovine PAs. However, it is noteworthy that in most tissues and in plasma steady-state $\mathrm{H}_{2} \mathrm{~S}$ levels do not exceed the nanomolar range $[63,64]$. In this range, $\mathrm{H}_{2} \mathrm{~S}$ preferentially relaxes PAs. A putative increase in intracellular $\mathrm{H}_{2} \mathrm{~S}$ levels from nanomolar range to $10 \mu \mathrm{M}$ in response to hypoxia would induce detrimental consequences on the mitochondria. Numerous considerations about variability in the experimental approaches $\left(\mathrm{H}_{2} \mathrm{~S}\right.$-releasing molecules, concentration, agonist-induced pre-tone of the vessel, oxygen levels, animal species, etc.) must be considered in order to explain opposing reports, and the development of reliable methods to control and measure intracellular $\mathrm{H}_{2} \mathrm{~S}$ levels are required. As previously mentioned, the use of pharmacological inhibitors of $\mathrm{H} 2 \mathrm{~S}$ enzymatic production also represents a significant issue, due to their relative specificity and the detrimental absence of selective CBS inhibitors [95].

\subsection{The Role of $\mathrm{H}_{2} \mathrm{~S}$ in Pulmonary Artery Relaxation}

Numerous studies associate $\mathrm{H}_{2} \mathrm{~S}$ with the regulation of vascular tone. The relaxing effects of exogenous $\mathrm{H}_{2} \mathrm{~S}$ in portal veins and thoracic aortae of rats $[25,27]$ were initially reported, and were associated with decreased arterial blood pressure $[27,28,109]$. For instance, CSE genetic deletion in mice reduces endothelium-dependent vasorelaxation, suggesting an important role of endogenous $\mathrm{H}_{2} \mathrm{~S}$ production in this process [28]. 
Initial reports of the effect of exogenous $\mathrm{H}_{2} \mathrm{~S}$ on PAs' vascular tone indicated that, at physiological levels, $\mathrm{H}_{2} \mathrm{~S}$ relaxes bovine PAs in a dose-dependent manner, with a half maximal effective concentration of $550 \pm 180 \mathrm{nM}$ [38] (Figure 3). High concentrations of $\mathrm{H}_{2} \mathrm{~S}(300 \mu \mathrm{M})$ also relax bovine PAs preconstricted by severe hypoxia [38]. NaHS induces a dose-dependent relaxation in rat PAs [42,47]. Exogenous $\mathrm{H}_{2} \mathrm{~S}(20-500 \mu \mathrm{M})^{\prime} \mathrm{s}$ relaxing effects were also observed in isolated large- and medium-sized PAs from human donors, and were associated with a decrease in PA pressure in human perfused lung tissues [111]. However, it should be noted that the genetic deletion of CSE in mice does not impact steady-state mPAP in isolated perfused lung tissues [109], suggesting that endogenous $\mathrm{H}_{2} \mathrm{~S}$ production by CSE is not involved in the regulation of basal mPAP, at least in mice. Derived organosulfur compounds from garlic, such as allicin, diallyl disulfide, and diallyl trisulfide, have for a long time been associated with $\mathrm{H}_{2} \mathrm{~S}$ release under physiological conditions, triggering vascular relaxation in systemic vessels and decreasing blood pressure [58,112]. In pulmonary vascular beds, allicin—but not diallyl disulfide or trisulfide-dose-dependently relaxed rat PAs and reduced PA pressure in rat perfused lung tissues $[113,114]$. Interestingly, pre-treatment with garlic extracts significantly decreased endothelin-1 contraction of rat PAs [115]. However, the contribution of $\mathrm{H}_{2} \mathrm{~S}$ release from these garlic-derived compounds to PA relaxation remains to be elucidated.

Cellular mechanisms underlying the relaxing effect of $\mathrm{H}_{2} \mathrm{~S}$ on PAs were primarily associated with $\mathrm{K}_{\text {ATP }}$ channel activity. Indeed, Zhao et al. demonstrated that $\mathrm{H}_{2} \mathrm{~S}$ promotes opening of $\mathrm{K}_{\text {ATP }}$ channels, leading to smooth muscle cell hyperpolarization and, consequently, aortic relaxation [27]. This result was then reproduced in pulmonary circulation, where glibenclamide (a blocker of plasma membrane $\mathrm{K}_{\mathrm{ATP}}$ ) — but not 5-hydroxydecanoate (blocker of mitochondrial $\mathrm{K}_{\text {ATP }}$ ) — partially inhibited $\mathrm{H}_{2} \mathrm{~S}$-induced PA relaxation in rats [42]. $\mathrm{H}_{2} \mathrm{~S}$ has been shown to directly interact with the Kir6.1 regulating subunit of $\mathrm{K}_{\text {ATP }}$ channels through S-sulfhydration (post-translational modification consisting in the formation of a persulfide group (R-SSH) on a cysteine residue) of cysteine residue (cys43) [116]. This modification of the $\mathrm{K}_{\mathrm{ATP}}$ regulating subunit alters ATP binding and, consequently, $\mathrm{K}_{\mathrm{ATP}}$ activity is enhanced, promoting hyperpolarization and vascular relaxation [116]. Although Kir6.1 was found in rat PAECs and PASMCs [42], no direct evidence links Kir6.1 S-sulfhydration and $\mathrm{H}_{2} \mathrm{~S}$-induced PA relaxation. In aortic tissue, $\mathrm{H}_{2} \mathrm{~S}$ inhibits mitochondrial metabolism, thus resulting in decreased ATP production [117]. Alteration of ATP levels promoting $\mathrm{K}_{\text {ATP }}$ activity could be another mechanism in $\mathrm{H}_{2} \mathrm{~S}$-induced PA relaxation. $\mathrm{H}_{2} \mathrm{~S}$ has long been known to interact with other gasotransmitters, such as $\mathrm{NO}$, through chemical or metabolic interplays [118]. For instance, $\mathrm{H}_{2} \mathrm{~S}$-induced relaxation of rat PAs is altered by $\mathrm{N} \omega$-nitro-L-arginine methyl ester (L-NAME), a potent NO synthase inhibitor [47]. PA relaxation triggered by sodium nitroprusside - an NO donor-is also partially reduced by PAG. Allicin-mediated PA relaxation is also dependent on the NO pathway [115]. Endogenous $\mathrm{NO}$ production thus seems to be involved in $\mathrm{H}_{2} \mathrm{~S}$ relaxation, and vice versa, establishing a possible metabolic crosstalk for PA tone regulation (Figure 3). Although precise mechanism(s) remain to be determined in the pulmonary vascular bed, these results are in accordance with numerous reports showing $\mathrm{H}_{2} \mathrm{~S}$ and $\mathrm{NO}$ pathway interactions in the modulation of systemic vascular tone $[25,28,119,120]$. Owing to the significant relaxing influence of $\mathrm{H}_{2} \mathrm{~S}$, many studies have shown a protective effect of $\mathrm{H}_{2} \mathrm{~S}$ on increased mPAP during $\mathrm{PH}$ development, which will be discussed in the following section. 


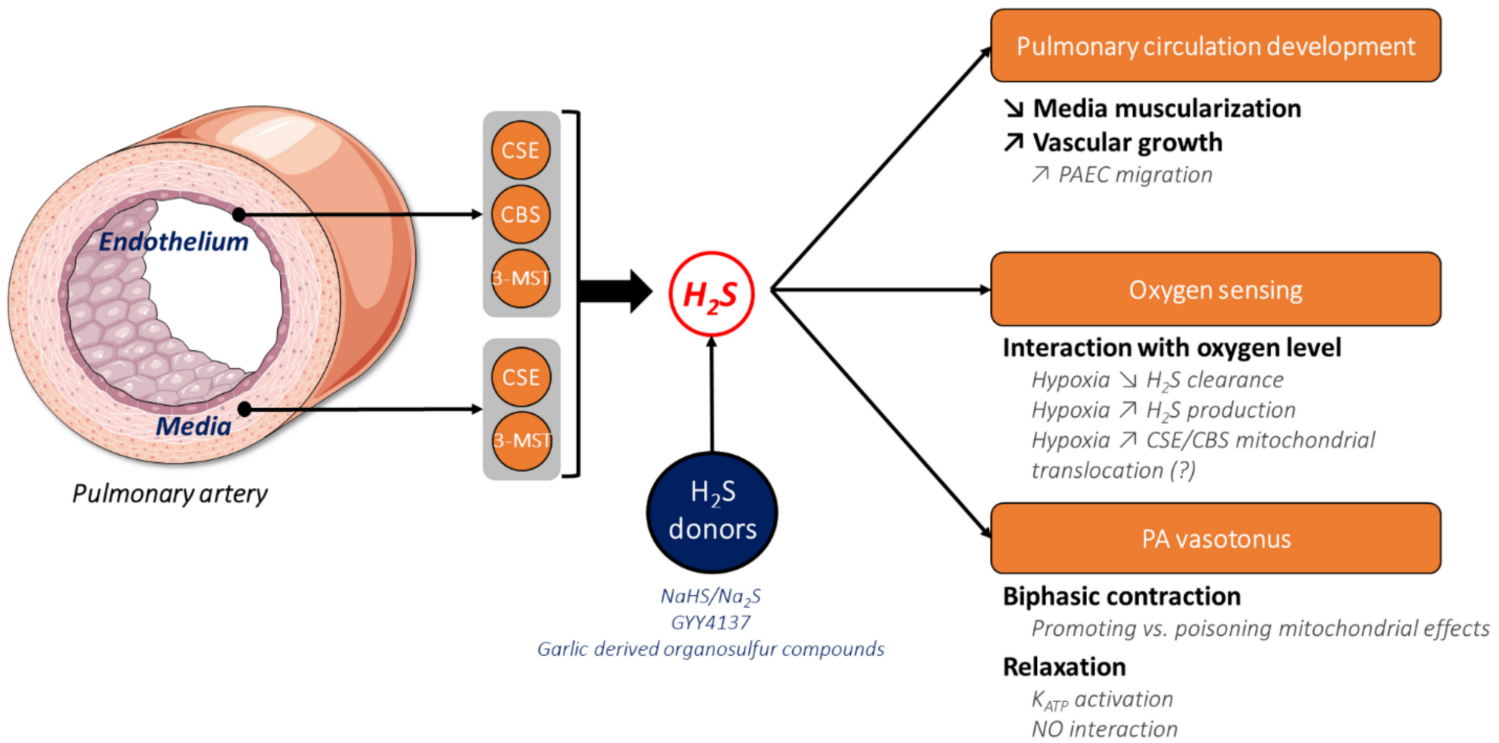

Figure 3. Endogenous production of $\mathrm{H}_{2} \mathrm{~S}$ and its roles in pulmonary circulation. $\mathrm{H}_{2} \mathrm{~S}$-producing enzymes have been found to be expressed in the endothelium and the media of pulmonary arteries. CSE and 3-MST are detected in both PAECs and PASMCs, whereas CBS exhibits an endothelial predominance. $\mathrm{H}_{2} \mathrm{~S}$ is involved in lung and PA development by (1) promoting vascular growth and associated PAEC migration and (2) decreasing media muscularization. Variation in the partial pressure of oxygen is linked to regulation of $\mathrm{H}_{2} \mathrm{~S}$ metabolism. Hypoxia exposure triggers a decrease in $\mathrm{H}_{2} \mathrm{~S}$ clearance and an increase in $\mathrm{H}_{2} \mathrm{~S}$ production, leading to a global elevation of intracellular $\mathrm{H}_{2} \mathrm{~S}$ levels. Modulation of the $\mathrm{H}_{2} \mathrm{~S}$ clearance/production balance may play a pivotal role in oxygen sensing in pulmonary circulation. PA treatment with $\mathrm{H}_{2} \mathrm{~S}$ donors is associated with paradoxical influence on vascular tone. On the one hand, $\mathrm{H}_{2} \mathrm{~S}$ induces biphasic contraction of PAs that could be explained by the balance of the promotion (oxidation by SQR) versus poisoning (blocking of complex IV) effects of $\mathrm{H}_{2} \mathrm{~S}$ on mitochondrial ETC function. In other hand, $\mathrm{H}_{2} \mathrm{~S}$ also dose-dependently relaxes PAs through the activation of $\mathrm{K}_{\mathrm{ATP}}$ channels, leading to vascular cells' hyperpolarization and, thus, to relaxation. Crosstalk between $\mathrm{H}_{2} \mathrm{~S}$ and endothelial NO pathways was also observed, suggesting a potential role of the endothelium in the relaxing effects of $\mathrm{H}_{2} \mathrm{~S}$. 3-MST: 3-mercaptopyruvate sulfur transferase; CSE: cystathionine $\gamma$-lyase; GYY4137: morpholin-4-ium 4-methoxyphenyl (morpholino) phosphinodithioate; $\mathrm{H}_{2} \mathrm{~S}$ : hydrogen sulfide; $\mathrm{K}_{\mathrm{ATP}}$ : ATP-sensitive $\mathrm{K}^{+}$channel; $\mathrm{Na}_{2} \mathrm{~S}$ : sodium sulfide; $\mathrm{NaHS}$ : sodium hydrosulfide; NO: nitric oxide; PA: pulmonary artery; PAECs: pulmonary artery endothelial cells; PASMCs: pulmonary artery smooth muscle cells.

\section{The Role of $\mathrm{H}_{2} \mathrm{~S}$ in Hallmarks of PH}

Alterations in $\mathrm{H}_{2} \mathrm{~S}$ production or clearance lead to a pathological drift contributing to vascular injury, notably through endothelial dysfunction, inflammation, oxidative stress, decreased vasorelaxation, vascular remodeling, and platelet aggregation (already reviewed in $[29,32,121,122])$. Depending on the considered pathological condition, circulating $\mathrm{H}_{2} \mathrm{~S}$ levels are either decreased or increased in patients [123-125]. High levels of homocysteine that promote endothelial dysfunction are also observed in various clinical cardiovascular conditions [122]. Therefore, the global vasculoprotective role of exogenous $\mathrm{H}_{2} \mathrm{~S}$ supplementation-especially through its anti-inflammatory, antioxidative, and vasorelaxant properties - argues in favor of $\mathrm{H}_{2} \mathrm{~S}$ acting as a new therapeutic strategy for vascular diseases. In view of the implications of $\mathrm{H}_{2} \mathrm{~S}$ in pulmonary circulation, we will discuss $\mathrm{H}_{2} \mathrm{~S}$ metabolism alterations in the setup of $\mathrm{PH}$, as well as the potential protective role of $\mathrm{H}_{2} \mathrm{~S}$ in the development of associated pathological hallmarks.

\section{1. $\mathrm{H}_{2} \mathrm{~S}$ Metabolism Alterations in $\mathrm{PH}$ \\ 4.1.1. $\mathrm{H}_{2} \mathrm{~S}$ Metabolism in Human PH}

According to PH classification (5 groups), PA pathological changes can be associated with a multitude of clinical conditions [2]. Congenital heart diseases (CHDs), such as Eisenmenger syndrome or systemic-to-pulmonary shunts, can promote $\mathrm{PH}$ development 
due to increased blood flow within pulmonary circulation (PH group 1) [2]. In children with CHD-associated $\mathrm{PH}$, circulating $\mathrm{H}_{2} \mathrm{~S}$ levels and CSE expression are lower than in children without $\mathrm{PH}$ [126]. In contrast, homocysteine levels are increased, but the low $\mathrm{H}_{2} \mathrm{~S}$ levels may be due to the reduced CSE expression, thus inducing a decrease in homocysteine conversion into L-cysteine via the transsulfuration pathway [126,127]. In addition, low endogenous $\mathrm{H}_{2} \mathrm{~S}$ was correlated with worse prognosis after surgical correction of CHD [128]. These results suggest that $\mathrm{H}_{2} \mathrm{~S}$ and actors of its metabolism (namely homocysteine and CSE) could be potential biomarkers to determine the short-term prognosis and risk of CHD complicated with PH.

Chronic hypoxia exposure triggers a cascade of pathological manifestations inducing $\mathrm{PH}$, characterized by a sustained PA contraction and decreased relaxation (endothelial dysfunction), PA remodeling, and inflammation, finally leading to right ventricle hypertrophy [4]. Indeed, lung hypoxic chronic diseases such as COPD, sleep apnea, or fibrosis/emphysema disorders are associated with $\mathrm{PH}$ development (PH group 3) [2,4]. $\mathrm{PH}$ is commonly observed in severe COPD, seen in more than $90 \%$ of patients with mPAP $>20 \mathrm{mmHg}$ [129]. COPD is mainly characterized by a marked inflammation of the airway tract, lung parenchyma, and pulmonary vasculature, contributing to exacerbations and leading to possible pathological drift towards $\mathrm{PH}$. An initial report mentioned that $\mathrm{H}_{2} \mathrm{~S}$ serum levels in patients with acute COPD exacerbation are lower than those with stable COPD [130]. In addition, $\mathrm{H}_{2} \mathrm{~S}$ levels are progressively reduced with the decrease of airway obstruction severity, and when systolic PAP is greater than or equal to $35 \mathrm{mmHg}$ in COPD patients with acute exacerbation [130]. In accordance with these results, a complementary study indicated that CSE protein and CBS mRNA expression were significantly decreased in COPD patients [131]. A reduction in exhaled $\mathrm{H}_{2} \mathrm{~S}$ levels was also found in COPD patients with significant quantities of eosinophils, suggesting a potential link with the modulation of inflammation [132].

BPD is a common lung developmental complication in premature newborns, characterized by an arrest of alveolarization and a decrease in angiogenesis due to the requirement of mechanical ventilation and hyperoxic treatment [133]. Those developmental alterations can lead to decreased pulmonary vascular density and promote PA muscularization and inflammation $[134,135]$. As a consequence, increased PA resistance and pressure can be observed, and $25-40 \%$ of premature infants with severe BPD will develop PH (BPD-PH). In case of BPD-PH, the death rate after 2 years is between 33 and $48 \%$ [136]. Although there are multiple pathophysiological mechanisms, dysregulation of $\mathrm{H}_{2} \mathrm{~S}$ metabolism was demonstrated in the context of BPD. Indeed, cystathionine plasma levels are higher in premature than in full-term newborns. In contrast, L-cysteine levels are significantly lower in premature infants [137]. Moreover, hepatic CSE activity is lower in premature than in mature infants [138]. This result brings evidence of a possible alteration of the transsulfuration pathway in pre-term newborns. However, the link between dysfunction of $\mathrm{H}_{2} \mathrm{~S}$ metabolism and the risk of developing BPD-associated $\mathrm{PH}$ is not yet elucidated.

Altogether, these results highlight an alteration of the endogenous $\mathrm{H}_{2} \mathrm{~S}$ metabolism in $\mathrm{CHD}$, COPD, and BPD, and could constitute an interesting biomarker of severity, prognosis, and risk to develop increased PAP.

\subsection{2. $\mathrm{H}_{2} \mathrm{~S}$ Metabolism in Experimental PH Models}

To understand the complex pathophysiology of $\mathrm{PH}$, various in vivo experimental models were developed to mimic clinical PH representations. Each experimental model has its own pathophysiology and etiology, although all exhibit, with different intensity, the primary markers of $\mathrm{PH}$-namely, pronounced PA remodeling, increased mPAP, inflammation, and RV hypertrophy [139]. The monocrotaline (MCT) animal model consisted of one injection of MCT - a pyrrolizidine alkaloid extracted from the plant Crotalaria spectabilismetabolized into its active form (MCT pyrrole) in the liver by monooxygenase. MCT triggers pulmonary vascular injury, mainly via endothelial dysfunction and exacerbated inflammation, leading to increased mPAP and both PA and RV remodeling [140]. Interest- 
ingly, MCT-treated rats exhibit lower $\mathrm{H}_{2} \mathrm{~S}$ levels in plasma and in lung tissue [34,141]. CSE protein expression and activity in lung tissue are also decreased in comparison to control rats $[50,141]$. These alterations are time-dependently downregulated in this $\mathrm{PH}$ model, with significant reductions in plasma $\mathrm{H}_{2} \mathrm{~S}$ levels, lung CSE expression, and activity from 14 days after MCT injection [50]. A treatment of human PAECs with the MCT pyrrole decreases $\mathrm{H}_{2} \mathrm{~S}$ production and CSE protein expression [141], suggesting a possible alteration of the endogenous $\mathrm{H}_{2} \mathrm{~S}$ metabolism in PA endothelium.

In order to model secondary PH due to chronic hypoxic diseases such as COPD, animals are subjected to hypoxia housing in normobaric or hypobaric chambers. Similarly to the MCT PH model, daily exposure to normobaric or hypobaric hypoxia $\left(10 \% \mathrm{O}_{2}\right)$ for 3 weeks was associated with a significant decrease of $\mathrm{H}_{2} \mathrm{~S}$ plasmatic concentration and lung $\mathrm{H}_{2} \mathrm{~S}$ production $[35,40,53,142,143]$. Moreover, expression of CSE mRNA was altered in lung tissues [35,40]. Interestingly, López et al. compared the effects of altitude exposition (hypobaric hypoxia) on newborn sheep versus newborn llamas, which are adapted to chronic exposition to hypoxia at high altitudes [144]. First of all, altitude exposition increased homocysteine plasma levels in sheep, but not in llamas, which presented basal low levels of homocysteine regardless of altitude. In addition, increased PA pressure and resistance were observed in sheep, but not in llamas, in response to altitude. Thus, basal low levels of homocysteine in llamas could be explained by their catabolism by CSE and CBS via the transsulfuration pathway, and may prevent the effects of hypoxic exposure and associated $\mathrm{PH}$. On the other hand, disruption of this route by an undefined hypoxia-dependent mechanism could trigger homocysteine accumulation and attenuate $\mathrm{H}_{2} \mathrm{~S}$ bioavailability, promoting vascular injury and $\mathrm{PH}$ setup. $\mathrm{PH}$ secondary to COPD and emphysema has also been studied in mice subjected to tobacco smoke [94]. After 12 or 24 weeks of tobacco smoke exposure, $\mathrm{H}_{2} \mathrm{~S}$ concentration was unchanged, whereas the capacity to produce $\mathrm{H}_{2} \mathrm{~S}$ was decreased in murine lungs [94]. Such results could be explained by the significant reduction of CSE and CBS protein expression [94].

Beyond commonly used PH models, experimental PH can also be provoked by creating a shunt between the abdominal aorta and the inferior vena cava in order to increase pulmonary blood flow. After 11 weeks, rats with high pulmonary blood flow exhibited reduced plasma and lung $\mathrm{H}_{2} \mathrm{~S}$ levels, as well as lung $\mathrm{H}_{2} \mathrm{~S}$ production rates [92,145]. CSE, CBS, and 3-MST protein expression were also reduced in the PAs of these rats [44]. Surprisingly, four weeks after shunt, $\mathrm{H}_{2} \mathrm{~S}$ concentration in the lung tissue was higher than in control rats. This elevation was suppressed with daily treatment with PAG (a CSE inhibitor), suggesting an increase in $\mathrm{H}_{2} \mathrm{~S}$ production caused by CSE $[93,145]$. Indeed, we can hypothesize that the increase in $\mathrm{H}_{2} \mathrm{~S}$ content in the lung tissue after four weeks could act as a compensatory mechanism to counteract the high PA pressures, perhaps via the relaxant properties of $\mathrm{H}_{2} \mathrm{~S}$ on PAs. Prolongation of high PAP could induce a decompensation state, with a decrease in $\mathrm{H}_{2} \mathrm{~S}$ production through the alteration of CSE, CBS, and 3-MST expression. Such hypotheses imply a cellular relationship between blood pressure detection and $\mathrm{H}_{2} \mathrm{~S}$ metabolism. Already mentioned in recent reports on systemic vessels [81,146], this association needs to be demonstrated in pulmonary circulation.

Overall, experimental models of PH tend to reproduce clinical observations of dysregulated $\mathrm{H}_{2} \mathrm{~S}$ metabolism in $\mathrm{PH}$, whatever the $\mathrm{PH}$ group considered. Circulating and pulmonary $\mathrm{H}_{2} \mathrm{~S}$ contents are decreased in most reports, and associated with altered expression and/or activity of $\mathrm{H}_{2} \mathrm{~S}$-generating enzymes. Dysregulation of CSE seems to be a pivotal common factor, since it is associated with various forms of $\mathrm{PH}$ in human and experimental models alike. Considering the major role of CSE in vascular tissues, and its involvement in endogenous $\mathrm{H}_{2} \mathrm{~S}$ synthesis in PAs (see Section 2.2), reduction of its expression and/or activity in the lungs could be associated with high homocysteine levels and decrease of $\mathrm{H}_{2} \mathrm{~S}$ vascular bioavailability. Finally, under pathological conditions, $\mathrm{H}_{2} \mathrm{~S}$ metabolism alterations could, at least in part, result in PA injury through the development of endothelial dysfunction, remodeling, and decreased vasorelaxation. Altogether, current 
clinical and experimental research converges to a critical protective role of $\mathrm{H}_{2} \mathrm{~S}$ metabolism in the pathophysiology of $\mathrm{PH}$, which will be discussed in next section.

\section{2. $\mathrm{H}_{2} \mathrm{~S}$ Exerts Protective Effects against $\mathrm{PH}$}

Research into the therapeutic potential of $\mathrm{H}_{2} \mathrm{~S}$ against $\mathrm{PH}$ is based on $\mathrm{H}_{2} \mathrm{~S}$ supplementation experiments using $\mathrm{H}_{2} \mathrm{~S}$-releasing molecules. The most commonly used are the sulfide salts $\mathrm{NaHS}$ and $\mathrm{Na}_{2} \mathrm{~S}$, which are inexpensive, water-soluble, and quickly release large amounts of $\mathrm{H}_{2} \mathrm{~S}$ under physiological conditions [54,55]. Slow-releasing $\mathrm{H}_{2} \mathrm{~S}$ donors, such as GYY4137 (morpholin-4-ium 4-methoxyphenyl (morpholino) phosphinodithioate), were further developed, and already exhibit interesting effects on cardiovascular diseases $[26,54,55]$. The beneficial effects of $\mathrm{H}_{2} \mathrm{~S}$-releasing molecules' administration on experimental PH development are summarized in Table 1.

In the MCT model, preventive daily injection of $\mathrm{NaHS}(56 \mu \mathrm{mol} / \mathrm{kg}$, intraperitoneal) for 21 days significantly reversed the reduced $\mathrm{H}_{2} \mathrm{~S}$ levels in plasma and in lung tissues, and decreased mPAP, RV hypertrophy, and PA remodeling via the reduction of media thickness $[34,141]$. This protective effect was also reported with a curative treatment with $\mathrm{NaHS}(1 \mathrm{mg} / \mathrm{kg}$, intraperitoneal) 7 days after MCT injection [50]. More surprisingly, decreased CSE protein expression was also reversed in rat lung tissue, suggesting a feedback influence of $\mathrm{H}_{2} \mathrm{~S}$ on its production routes [141]. In the same manner, low CSE protein expression observed in human PAECs treated with MCT pyrrole in vitro was reversed by the addition of $\mathrm{H}_{2} \mathrm{~S}$ [141]. The protective influence of $\mathrm{NaHS}$ was associated with an inhibition of $\mathrm{PH}$-associated inflammation, as shown by reduction of the plasmatic and pulmonary contents of the proinflammatory cytokines TNF- $\alpha$, IL-6, and IL-8 [34,141]. $\mathrm{H}_{2} \mathrm{~S}$ supplementation attenuated the activation of the nuclear factor kappa B (NF- $\mathrm{kB}$ ) pathwaya pivotal signaling pathway in inflammation in $\mathrm{PH}[147,148]$ - in lung tissue from rats with MCT-associated PH [141] and in PAECs treated with MCT pyrrole [37,141]. Moreover, $\mathrm{NaHS}$ treatment reduces $\alpha$-smooth muscle actin and increases VE-cadherin expression in the PAs of rats injected with MCT [50]. This effect was aggravated when rats were treated with PAG. NaHS also dose-dependently inhibited the in vitro phenotypic shift of human PAECs into mesenchymal cells induced by TGF- $\beta 1$ treatment [50]. This process was mimicked by CSE overexpression. Altogether, these results suggest that $\mathrm{H}_{2} \mathrm{~S}$ inhibits the endothelial-mesenchymal transition and associated remodeling observed in $\mathrm{PH}$. In contrast to $\mathrm{NaHS}$, dithiolthione (ADT-OH) was demonstrated to slowly release $\mathrm{H}_{2} \mathrm{~S}$ in vivo [149]. Interestingly, 7 days after MCT injection, daily inhalation of ACS14 (a conjunction of ADT-OH and aspirin) encapsulated in a large porous microsphere decreased mPAP, PA remodeling, and RV hypertrophy, similarly to sildenafil, which is known to decrease such PH hallmarks [56]. Like NaHS, ACS14 treatment also reduced endothelial-mesenchymal transition in the PA walls of rats injected with MCT.

In the hypoxia model, daily administration of $\mathrm{NaHS}(14 \mu \mathrm{mol} / \mathrm{kg})$ also demonstrated promising properties in PH. NaHS markedly inhibited mPAP in rats and broilers with hypoxic PH [35,40,53,142,143]. PA remodeling was also improved, with reduction of media thickness, the number of muscularized PAs, and the presence of collagen types I/III and elastin in PAs [35,143]. In addition, NaHS increased the total antioxidant capacity of lung homogenates, highlighting an improvement in cellular defenses against hypoxiainduced oxidative stress [53]. As in MCT models, NaHS treatment succeeded in reversing altered plasma and pulmonary $\mathrm{H}_{2} \mathrm{~S}$ levels $[35,40,53,142,143]$. In the murine tobacco smokeinduced PH model, daily treatment with NaHS $(50 \mu \mathrm{mol} / \mathrm{kg})$ decreased TNF- $\alpha$ amounts in bronchial alveolar lavage- and 8-hydroxyguanine (a marker of DNA injury induced by ROS)-positive cells, suggesting an attenuation of lung inflammation and oxidative stress. Moreover, NaHS treatment restored murine lung expression of CSE and CBS proteins due to Akt protein activation [94]. Interestingly, these results were associated with a reduction in RV systolic pressure [94]. In another model of rats with COPD obtained via smoke exposure and lipopolysaccharide tracheal instillation, Ding et al. showed the beneficial effects of NaHS $(56 \mu \mathrm{mol} / \mathrm{kg})$ on PAEC apoptosis and associated endothelial injury [150]. Further- 
more, a recent work analyzed the therapeutic potential of a preventive treatment with a slow-releasing $\mathrm{H}_{2} \mathrm{~S}$ donor-GYY4137-on hypoxic $\mathrm{PH}$ [51]. Partial reduction of mPAP and total PA resistance (mPAP/cardiac output ratio) was reported in rats subjected to 4 weeks of hypoxia and treated with GYY4137. PA media thickness was also decreased, which is consistent with the inhibition by GYY4137 $(100 \mu \mathrm{M})$ of hypoxia-induced PASMC proliferation and migration, without inducing apoptosis [51]. ER stress was recently considered to be a pivotal manifestation during $\mathrm{PH}$ setup, and notably characterized by stimulation of the activating transcription factor 6 (ATF6) and disruption of ER-mitochondria interactions [151]. GYY4137 inhibited the expression of ER-stress-associated proteins binding the immunoglobulin protein (Grp78) and ATF6 in PAs [51]. However, as already demonstrated in HUVEC [152], the influence of GYY4137 on the ER-mitochondria unit remains to be defined in PA walls. It is important to note that, in addition to vascular benefits, NaHS and GYY4137 also demonstrated protective effects on cardiac function and remodeling, both in hypoxic PH and in PH secondary to COPD [35,51,53,94]. Beyond NaHS and GYY4137, garlic was studied for its short-term hemodynamic properties on pulmonary circulation. Indeed, daily treatment of rats with garlic by gavage $(100 \mathrm{mg} / \mathrm{kg})$ for 5 days significantly reduced the increase in $\mathrm{mPAP}$ induced by $90 \mathrm{~min}$ of hypoxia housing $\left(10 \% \mathrm{O}_{2}\right)$, without modifying systemic arterial pressure [57]. This effect was related to the relaxant influence of garlic on PAs (see Section 3.3).

An experimental model of BPD-PH was induced by exposing mouse or rat pups to hyperoxia during their first days of life. Such conditions promote lung inflammation, alveolar/vascular growth inhibition, increase in PA wall thickness and, consequently, $\mathrm{PH}[52,153]$. Vadivel et al. assessed the benefits of daily administration with GYY4137 on hyperoxia $\left(95 \% \mathrm{O}_{2}\right)$-induced $\mathrm{BPD}-\mathrm{PH}$ in rat pups [52]. This treatment reduced PASMC proliferation, PA media remodeling, and RV afterload, and partially attenuated RV hypertrophy, suggesting that GYY4137 could prevent vascular and cardiac adverse manifestations in BPD-PH. This beneficial effect was associated with an improvement of alveolar growth and pulmonary vessel density in lungs. Vascular growth alteration under hyperoxia is primarily due to a reduced networking of PAECs. Interestingly, GYY4137 treatment improved human PAEC network formation in normoxia or hyperoxia [52,90]. In relation to these results, GYY4137 also improved cell viability and reduced oxidative stress induced by hyperoxia in human PAECs, suggesting that such a compound could have a beneficial effect on PA remodeling [52]. The protective effects of $\mathrm{H}_{2} \mathrm{~S}$ against BPD-PH are in total accordance with $\mathrm{H}_{2} \mathrm{~S}$ 's significant role in both lung and pulmonary circulation in post-natal development (see Section 3.1).

Finally, in the model of high pulmonary blood flow $\mathrm{PH}, \mathrm{H}_{2} \mathrm{~S}$ donors also revealed interesting properties. Indeed, daily NaHS $(56 \mu \mathrm{mol} / \mathrm{kg})$ administration during the 11 weeks of shunting partially attenuated increased mPAP and RV hypertrophy $[48,143,145]$. Improvement of PA structural alteration was observed with a reduction of PA remodeling and collagen type I/III staining in the PA walls [48]. In PA media from rats treated with NaHS, an increase in apoptosis markers—such as Fas and caspase-3-was observed [145]. It must be noted that NaHS also reversed the increased lung endothelin-1 levels-a potent vasoactive and pro-proliferative agent [48].

Beyond vascular manifestations, $\mathrm{PH}$ is also characterized by critical structural alterations (e.g., inflammation, fibrosis, remodeling, etc.) of the RV, resulting in RV failure and death [3]. $\mathrm{H}_{2} \mathrm{~S}$ administration in $\mathrm{PH}$ experimental models showed beneficial effects on $\mathrm{RV}$ hypertrophy (see Section 4.2). Nevertheless, mechanisms underlying this influence are still undetermined; two options may merit further examination-namely, a direct effect on the myocardium, and/or an indirect process via attenuation of the RV afterload. Numerous studies reported the relationship between decreased plasma $\mathrm{H}_{2} \mathrm{~S}$ levels and myocardial infarction or heart failure, suggesting an intrinsic role of $\mathrm{H}_{2} \mathrm{~S}$ metabolism in cardiac homeostasis [154]. In both experimental and clinical cases, $\mathrm{H}_{2} \mathrm{~S}$ administration using SG-1002-a slow-releasing $\mathrm{H}_{2} \mathrm{~S}$ donor-exerted cardioprotective effects on heart failure through a proposed increase of both circulating NO bioavailability and the eNOS pathway $[155,156]$. 
In addition, liposomal ZYZ-802-another slow-releasing $\mathrm{H}_{2} \mathrm{~S}$ molecule-reduced collagen fiber amounts and associated fibrosis in the myocardium in a heart failure model of rats [157].

At the mitochondrial level, $\mathrm{PH}$ is characterized by a cancer-like metabolic shift (Warburg effect) from oxidative phosphorylation to glycolysis in both PA and RV cells. Mitochondrial fission through increased dynamin-related protein 1 (DRP1) and decreased mitofusin 2 (MFN2) has also been demonstrated [158]. Interestingly, $\mathrm{H}_{2} \mathrm{~S}$ oxidation by $\mathrm{SQR}$ stimulates oxidative phosphorylation, presenting the mitochondria as a privileged target of $\mathrm{H}_{2} \mathrm{~S}[65,80] . \mathrm{H}_{2} \mathrm{~S}$ can also interact with the expression and function of proteins regulating mitochondrial dynamics. In fact, $\mathrm{H}_{2} \mathrm{~S}$ decreases DRP1 and enhances MFN2 expression in the myocardium, and subsequently improves mitochondrial ultrastructure and function $[159,160]$. These beneficial effects were associated with an attenuation of myocardial hypertrophy in mice $[159,160]$. Moreover, CBS knockdown or inhibition using AOA was associated with a reduction of MFN2 expression in ovarian cancer cells [161]. In relation to its role in oxygen sensing and hypoxia responses in PAs (see Section 3.2), $\mathrm{H}_{2} \mathrm{~S}$ could thus be of interest to reduce or reverse mitochondrial alterations associated with $\mathrm{PH}$.

In summary, $\mathrm{H}_{2} \mathrm{~S}$-releasing molecules show significant protective effects on vascular and cardiac manifestations of various forms of $\mathrm{PH}$ in experimental $\mathrm{PH}$ models. $\mathrm{H}_{2} \mathrm{~S}^{\prime} \mathrm{s}$ beneficial effects on $\mathrm{PH}$ are multifaceted on various hallmarks, such as inflammation, PA remodeling (endothelial-mesenchymal transition; migration and proliferation of cells from the PA walls), and oxidative and ER stress (Figure 4). $\mathrm{H}_{2} \mathrm{~S}$-based preventive and curative treatments improved endogenous $\mathrm{H}_{2} \mathrm{~S}$ production, especially by CSE, which appeared to be critical in the regulation of $\mathrm{PH}$ hallmarks. To date, the lack of studies using GYY4137 or other slow-releasing $\mathrm{H}_{2} \mathrm{~S}$ donors on $\mathrm{PH}$ does not allow for comparison of their effects with those of sulfide salts, such as NaHS. However, slow-releasing $\mathrm{H}_{2} \mathrm{~S}$ donors seem to better control $\mathrm{H}_{2} \mathrm{~S}$ rates, thus avoiding high $\mathrm{H}_{2} \mathrm{~S}$ levels, which could be deleterious to mitochondria [54,55]. Although NaHS decreases lung ET-1 levels [48], the effect of preventive $\mathrm{H}_{2} \mathrm{~S}$ donor supplementation on the decreased PA relaxation and hyper-reactivity observed in $\mathrm{PH}$ remains to be assessed.

Table 1. Summary of reported effects of the use of $\mathrm{H}_{2}$ S-releasing molecules on various experimental PH models. $\alpha$-SMA: $\alpha$ smooth muscle cell actin; ATF6: activating transcription factor 6; BAL: bronchial alveolar lavage; CO: carbon monoxide; ET-1: endothelin-1; ER: endoplasmic reticulum; GYY4137: morpholin-4-ium 4-methoxyphenyl (morpholino) phosphinodithioate; Grp78: binding immunoglobulin protein; HO-1: heme oxygenase-1; ICAM-1: intercellular adhesion molecule-1; mPAP: mean pulmonary artery pressure; NaHS,: sodium hydrosulfide; PA: pulmonary artery; PAECs: pulmonary artery endothelial cells; PASMCs: pulmonary artery smooth muscle cells; RV: right ventricle; TNF- $\alpha$ : tumor necrosis factor- $\alpha$; IL-6/8: interleukin 6/8; VE-cadherin: vascular endothelial-cadherin.

\begin{tabular}{|c|c|c|c|c|}
\hline $\begin{array}{l}\text { Experimental } \\
\text { Models }\end{array}$ & $\begin{array}{l}\mathrm{H}_{2} \mathrm{~S} \text {-Releasing } \\
\text { Molecules }\end{array}$ & Animal Species & $\begin{array}{l}\text { Summary of Reported } \\
\text { Effects on PH }\end{array}$ & References \\
\hline \multirow{4}{*}{ MCT } & $\begin{array}{c}\text { NaHS } \\
56 \mu \mathrm{mol} / \mathrm{kg} / \text { day } \\
\text { (21 days) }\end{array}$ & Wistar rat & $\begin{array}{c}\searrow \text { mPAP } \\
\searrow \text { RV hypertrophy } \\
\searrow \text { PA remodeling } \\
\searrow \text { ICAM-1, TNF- } \alpha \text {, IL-6, IL-8 MCP-1 } \\
\text { (plasma and lung) }\end{array}$ & [141] \\
\hline & $\begin{array}{c}\mathrm{NaHS} \\
56 \mu \mathrm{mol} / \mathrm{kg} / \text { day } \\
\text { (21 days) }\end{array}$ & Wistar rat & $\begin{array}{c}\searrow \text { mPAP } \\
\searrow \text { TNF- } \alpha, \text { IL-6 (lung) }\end{array}$ & [34] \\
\hline & $\begin{array}{c}\mathrm{NaHS} \\
1 \mathrm{mg} / \mathrm{kg} / \text { day } \\
\text { (7 days after MCT injection) }\end{array}$ & Sprague Dawley rat & $\begin{array}{c}\searrow \text { mPAP } \\
\searrow \text { RV hypertrophy } \\
\searrow \text { PA remodeling } \\
\nearrow \text { RV ejection fraction } \\
\nearrow \text { VE-cadherin, } \searrow \alpha \text {-SMA (PA) }\end{array}$ & [50] \\
\hline & $\begin{array}{c}\text { ACS } 14 \\
46.5 \mathrm{mg} / \mathrm{kg} \\
\text { (7 days after MCT injection) }\end{array}$ & $\begin{array}{l}\text { Sprague } \\
\text { Dawley rat }\end{array}$ & $\begin{array}{c}\searrow \text { mPAP } \\
\searrow \text { RV hypertrophy } \\
\searrow \text { PA remodeling } \\
\nearrow \text { RV ejection fraction } \\
\nearrow \text { VE-cadherin, } \searrow \alpha \text {-SMA (PA) }\end{array}$ & [56] \\
\hline
\end{tabular}


Table 1. Cont.

\begin{tabular}{|c|c|c|c|c|}
\hline $\begin{array}{l}\text { Experimental } \\
\text { Models }\end{array}$ & $\begin{array}{c}\mathrm{H}_{2} \mathrm{~S} \text {-Releasing } \\
\text { Molecules }\end{array}$ & Animal Species & $\begin{array}{l}\text { Summary of Reported } \\
\text { Effects on PH }\end{array}$ & References \\
\hline \multirow{7}{*}{ Hypoxia-induced PH } & $\begin{array}{c}\mathrm{NaHS} \\
14 \mu \mathrm{mol} / \mathrm{kg} / \text { day } \\
\text { (21 days) }\end{array}$ & Wistar rat & $\begin{array}{c}\searrow \text { mPAP } \\
\searrow \text { RV hypertrophy } \\
\searrow \text { PA remodeling }\end{array}$ & [35] \\
\hline & $\begin{array}{c}\mathrm{NaHS} \\
14 \mu \mathrm{mol} / \mathrm{kg} / \text { day } \\
\text { (21 days) }\end{array}$ & Wistar rat & $\begin{array}{c}\searrow \text { mPAP } \\
\nearrow \text { CO (Plasma) } \\
\nearrow \text { HO-1 (PA media) }\end{array}$ & [142] \\
\hline & $\begin{array}{c}\mathrm{NaHS} \\
14 \mu \mathrm{mol} / \mathrm{kg} / \text { day } \\
\text { (21 days) }\end{array}$ & Wistar rat & $\begin{array}{c}\searrow \mathrm{mPAP} \\
\searrow \text { number of muscularized PA } \\
\text { collagen type I/III, elastin } \\
\text { (PA media) }\end{array}$ & [143] \\
\hline & $\begin{array}{c}\mathrm{NaHS} \\
14 \mu \mathrm{mol} / \mathrm{kg} / \text { day } \\
\text { (21 days) }\end{array}$ & Wistar rat & $\begin{array}{c}\searrow \text { mPAP } \\
\searrow \text { RV hypertrophy } \\
\nearrow \text { total antioxidant capacity (lung) }\end{array}$ & [53] \\
\hline & $\begin{array}{c}\mathrm{NaHS} \\
10 \mu \mathrm{mol} / \mathrm{kg} / \text { day } \\
\text { (21 days) }\end{array}$ & Broiler & $\begin{array}{c}\searrow \text { mPAP } \\
\searrow \text { PA remodeling }\end{array}$ & [40] \\
\hline & $\begin{array}{l}\text { Garlic powder } \\
100 \mathrm{mg} / \mathrm{kg} / \text { day } \\
\text { (5 days })\end{array}$ & Sprague Dawley rat & $\begin{array}{c}\searrow \mathrm{mPAP} \\
\nearrow \text { relaxation intralobar PA } \\
(90 \text { min hypoxia })\end{array}$ & [57] \\
\hline & $\begin{array}{l}\text { GYY4137 (concentration not } \\
\text { reported, daily, } 4 \text { weeks) }\end{array}$ & Sprague Dawley rat & $\begin{array}{c}\searrow \text { mPAP, and PA resistances } \\
\searrow \text { RV hypertrophy } \\
\searrow \text { PA remodeling } \\
\nearrow \text { treadmill running distance } \\
\searrow \text { RE stress proteins } \\
\text { ATF6 and Grp78 (PA) }\end{array}$ & [51] \\
\hline \multirow{2}{*}{ COPD models } & $\begin{array}{c}\mathrm{NaHS} \\
50 \mu \mathrm{mol} / \mathrm{kg} / \text { day } \\
\text { (12 or } 24 \text { weeks) }\end{array}$ & C57BL/ 6 mice & $\begin{array}{c}\searrow \text { mPAP } \\
\searrow \text { RV hypertrophy } \\
\searrow \text { TNF- } \alpha \text { (BAL) } \\
\searrow \text { 8-hydroxyguanine (lung) }\end{array}$ & [94] \\
\hline & $\begin{array}{c}\mathrm{NaHS} \\
56 \mu \mathrm{mol} / \mathrm{kg} / \text { day } \\
\text { (60 days) }\end{array}$ & Sprague Dawley rat & $\searrow$ apoptosis of PAEC & [150] \\
\hline \multirow{2}{*}{ High pulmonary blood flow } & $\begin{array}{c}\mathrm{NaHS} \\
56 \mu \mathrm{mol} / \mathrm{kg} / \text { day } \\
\begin{array}{c}(11 \text { weeks }) \\
\text { (n) }\end{array}\end{array}$ & Sprague Dawley rat & $\begin{array}{c}\searrow \text { mPAP } \\
\searrow \text { PA remodeling } \\
\searrow \text { collagen type I/III (PA) } \\
\searrow \text { ET-1 (lung) }\end{array}$ & [48] \\
\hline & $\begin{array}{c}\mathrm{NaHS} \\
56 \mu \mathrm{mol} / \mathrm{kg} / \text { day } \\
\begin{array}{c}(11 \text { weeks }) \\
\text { (n) }\end{array}\end{array}$ & Sprague Dawley rat & $\begin{array}{c}\searrow \mathrm{mPAP} \\
\nearrow \mathrm{PASMC} \text { apoptosis }\end{array}$ & [145] \\
\hline BDP-PH & $\begin{array}{l}\text { GYY4137 } \\
37.75 \mathrm{mg} / \mathrm{kg} / \text { day } \\
\text { (10 days) }\end{array}$ & Newborn rat pups & $\begin{array}{c}\searrow \text { PA remodeling } \\
\searrow \text { RV afterload and hypertrophy } \\
\nearrow \text { pulmonary vessels density }\end{array}$ & [52] \\
\hline
\end{tabular}




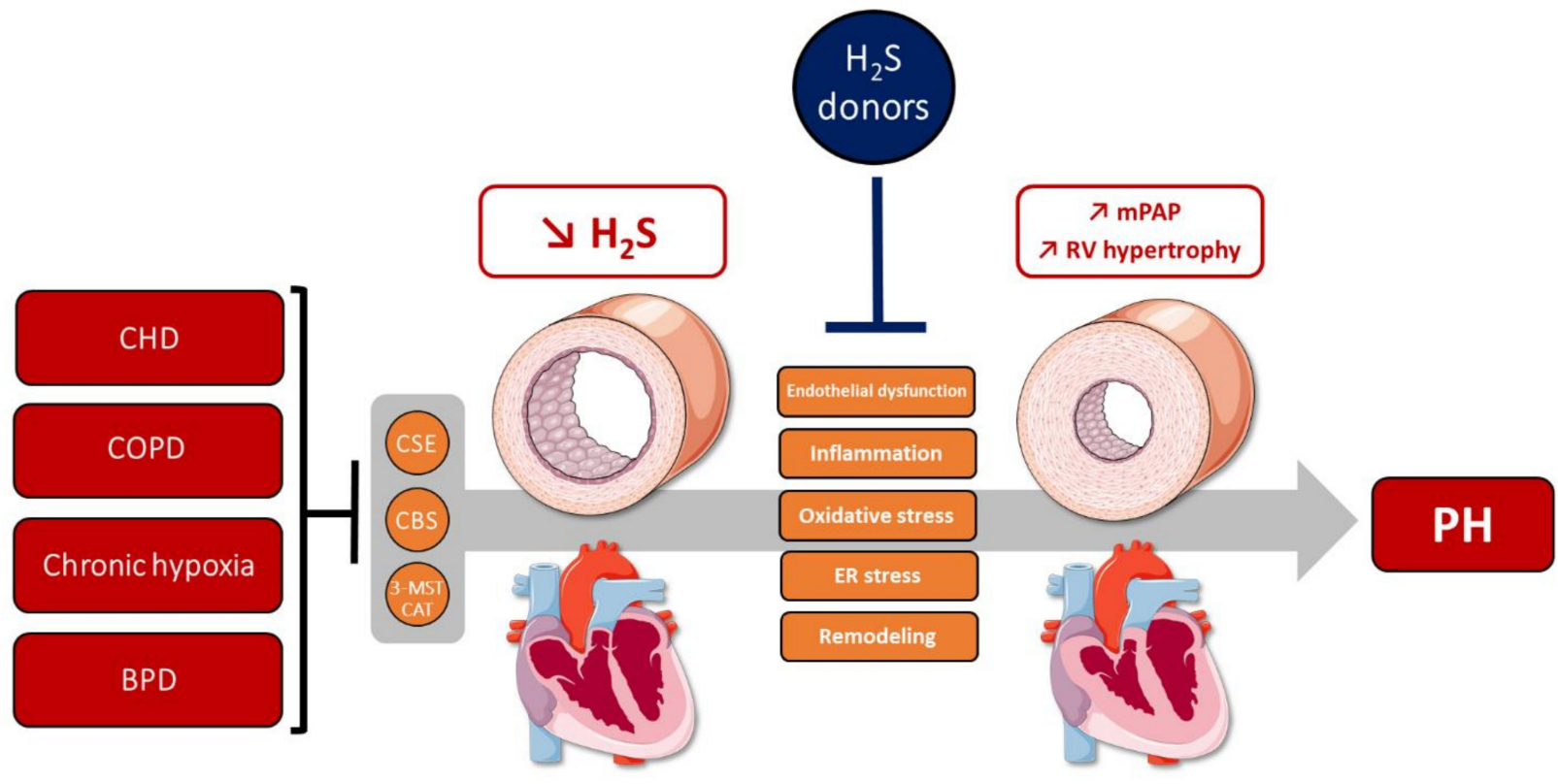

Figure 4. Alteration of $\mathrm{H}_{2} \mathrm{~S}$ metabolism and protective influence of $\mathrm{H}_{2} \mathrm{~S}$ donors on $\mathrm{PH}$ hallmarks. Clinical and experimental data suggest a pivotal dysregulation of endogenous $\mathrm{H}_{2} \mathrm{~S}$ production through the inhibition of activity and/or expression of $\mathrm{H}_{2} \mathrm{~S}$-generating enzymes (namely, CSE, CBS, and 3-MST/CAT). These alterations promote the development of PHassociated hallmarks in PA, such as endothelial dysfunction, inflammation, and oxidative and ER stress, as well as increased media thickness of PAs. Altogether these pathological phenomena lead to increased PA resistance, mPAP, subsequent RV hypertrophy and, finally, $\mathrm{PH}, \mathrm{H}_{2} \mathrm{~S}$ donors such as NaHS and GYY4137 demonstrate multifaceted protective effects on PA alterations, counteracting PH development. 3-MST: 3-mercaptopyruvate sulfur transferase; BPD: bronchopulmonary dysplasia; CAT: cysteine aminotransferase; CBS: cystathionine $\beta$-synthase; CHDs: congenital heart diseases; COPD: chronic obstructive pulmonary disease; CSE: cystathionine $\gamma$-lyase; ER: endoplasmic reticulum; $\mathrm{H}_{2} \mathrm{~S}$ : hydrogen sulfide; mPAP: mean pulmonary artery pressure; PA: pulmonary artery; PASMCs: pulmonary artery smooth muscle cells; PH: pulmonary hypertension; RV: right ventricle. Flat arrows represent inhibition interactions.

\section{Conclusions and Clinical Perspectives}

\section{1. $\mathrm{H}_{2} \mathrm{~S}$ Significance and Perspectives in $\mathrm{PH}$}

Like $\mathrm{NO}$ and $\mathrm{CO}$, the effect of $\mathrm{H}_{2} \mathrm{~S}$ in the regulation of vascular homeostasis and fundamental functions is undeniable. $\mathrm{H}_{2} \mathrm{~S}$ production takes part in pulmonary circulation development and oxygen sensing, and acts as a potent vasodilator. Alterations of endogenous $\mathrm{H}_{2} \mathrm{~S}$ metabolism are observed in various clinical cardiovascular conditions [123-125], including $\mathrm{PH}$ and associated diseases such as CHD, COPD, and BPD (see Section 4.1.1). Although the cellular mechanisms of these dysregulations remain unclear, decreased $\mathrm{H}_{2} \mathrm{~S}$ bioavailability is critical in the promotion of endothelial dysfunction, exacerbated inflammation, oxidative stress, and changes in the proliferative behavior of smooth muscle cells in the PA walls. In future clinical investigations, $\mathrm{H}_{2} \mathrm{~S}$ and associated metabolism actors (namely, L-cysteine, homocysteine, CSE, CBS, and 3-MST) could thus be considered to be relevant biomarkers to characterize prognosis and risk of developing $\mathrm{PH}$ from $\mathrm{CHD}$, COPD, or BPD. Enzymatic pathway production is considered to be the major route of $\mathrm{H}_{2} \mathrm{~S}$ production in PAs. However, non-enzymatic $\mathrm{H}_{2} \mathrm{~S}$ production by red blood cells from L-cysteine and iron has been recently evidenced as a new source of circulating $\mathrm{H}_{2} \mathrm{~S}$ under physiological conditions [59]. Interestingly, patients with severe $\mathrm{PH}$ exhibit iron deficiency [162]. Hypothetically, reduced iron levels could lead to a reduction of nonenzymatic $\mathrm{H}_{2} \mathrm{~S}$ production by red blood cells and, consequently, decreased circulating $\mathrm{H}_{2} \mathrm{~S}$ bioavailability in vascular tissues. Although interesting, this hypothesis needs to be experimentally proven in the context of $\mathrm{PH}$. 


\section{2. $\mathrm{H}_{2}$ S-Releasing Molecules as a New Therapeutic Strategy for PH?}

As discussed above, endogenous $\mathrm{H}_{2} \mathrm{~S}$ alterations in $\mathrm{PH}$ patients and the beneficial impacts of $\mathrm{H}_{2} \mathrm{~S}$ on the experimental pathophysiology of $\mathrm{PH}$ raise the issue of its clinical potential interest for $\mathrm{PH}$. In the past few years, multiple pharmacological tools have been developed in order to manipulate $\mathrm{H}_{2} \mathrm{~S}$ under physiological conditions. Sulfide salts were shown to release $\mathrm{H}_{2} \mathrm{~S}$ in large amounts, allowing for quick and efficient distribution. In healthy humans, Toombs et al. showed that intravascular administration of $\mathrm{Na}_{2} \mathrm{~S}$ induces an increase in the blood concentration of $\mathrm{H}_{2} \mathrm{~S}$ and thiosulfates, as well as exhaled $\mathrm{H}_{2} \mathrm{~S}$ levels, during the first minutes after injection [86]. However, this $\mathrm{H}_{2} \mathrm{~S}$ bolus released by sulfide salts could activate the detrimental effects of $\mathrm{H}_{2} \mathrm{~S}$ on mitochondrial function if high concentrations are reached, especially with susceptible individuals, as in patients with $\mathrm{PH}$. Slow-releasing $\mathrm{H}_{2} \mathrm{~S}$ donors, such as GYY4137 or dithiolthione compounds, thus represent an attractive alternative, since they exhibit interesting effects with prolonged liberation in vivo $[55,149]$. This characteristic avoids the bolus effect of sulfide salts, and allows a controlled release and a greater bioavailability of $\mathrm{H}_{2} \mathrm{~S}$ to mimic endogenous $\mathrm{H}_{2} \mathrm{~S}$ production rates and maintain a relevant concentration for a long period of time. Interestingly, numerous $\mathrm{H}_{2} \mathrm{~S}$ donors are currently considered to be safe for a clinical application. Natural $\mathrm{H}_{2} \mathrm{~S}$ donors, such as garlic extracts, have already demonstrated significant influence in lowering the blood pressure of hypertensive patients in multiple clinical trials [163]. Although efficient and highly safe, garlic supplementation should be considered as more of a co-treatment than a unique strategy, because of the lack of hindsight on long-term cardiovascular efficiency [163]. Anethole trithione (CAS number 532-11-6)-a dithiolthione compound - has been widely used and marketed for decades to treat salivary deficiency, cholecystitis, and hepatitis, with no known major side effects [164]. The structural versatility of dithiolthione compounds offers a multitude of plausible strategies to conjugate their $\mathrm{H}_{2} \mathrm{~S}$-releasing properties with other active molecules to improve $\mathrm{PH}$ hallmarks [54]. In this framework, dithiolthione was conjugated with sildenafil (ACS-6, http: / / www.ctgpharma.com, accessed on 10 June 2021) to associate the vasculoprotective features of $\mathrm{H}_{2} \mathrm{~S}$ with an established treatment of $\mathrm{PH}$ (sildenafil) [165]. As sildenafil, ACS-6 inhibits phosphodiesterase type 5 (PDE5) activity and TNF- $\alpha$-induced superoxide formation in PAECs in vitro [165]. $\mathrm{H}_{2} \mathrm{~S}$ release by ACS-6 is more sustained than that by NaHS. Nevertheless, the preclinical potential of this molecule on experimental PH models has not yet been assessed. Other $\mathrm{H}_{2} \mathrm{~S}$-liberating molecules have been, or are being, studied in various cardiovascular clinical contexts, and subjected to patenting [166]. For instance, the aforementioned SG-1002 (clinicaltrials.gov; ID: NCT01989208) has been clinically tested to counteract $\mathrm{H}_{2} \mathrm{~S}$ deficiency in heart failure patients. This compound is well tolerated at various doses, and no changes on hemodynamic parameters or clinical chemistry have been found in healthy or heart failure patients [155].

In summary, $\mathrm{H}_{2} \mathrm{~S}$-releasing molecules have already shown promising features to attenuate vascular and heart alterations in PH. Nevertheless, $\mathrm{H}_{2} \mathrm{~S}$ donor research is emerging, and clinical data in the context of $\mathrm{PH}$ are still lacking. It will be pertinent to compare the efficiency of various $\mathrm{H}_{2} \mathrm{~S}$-releasing molecules on the development of $\mathrm{PH}$ hallmarks in experimental models. Moreover, it will be relevant to decipher the specific actions and mechanisms of such treatment on RV functional and structural alterations during $\mathrm{PH}$ development. Innovative synthetic as well as natural $\mathrm{H}_{2} \mathrm{~S}$-releasing molecules, with their broad spectrum of action on vascular and cardiac manifestations, thus constitute a relevant opportunity to develop new therapeutic strategies for $\mathrm{PH}$, and further preclinical investigations on animal models are required prior to any clinical implementation.

Author Contributions: L.R. and C.G. wrote and edited the manuscript. B.L.G. and R.M. edited the manuscript. All authors have approved the final version. All authors have read and agreed to the published version of the manuscript.

Funding: L.R. and B.L.G. are employed by OP2 Drugs.

Institutional Review Board Statement: Not applicable. 
Informed Consent Statement: Not applicable.

Data Availability Statement: No new data were created or analyzed in this study. Data sharing is not applicable to this article.

Acknowledgments: The authors would like to thank Philippe Diolez for his careful and critical reading of the manuscript. The authors would also like to thank Servier Medical Art (https://smart. servier.com/, accessed on 10 June 2021) for providing the images in Figures 3 and 4.

Conflicts of Interest: The authors declare no conflict of interest.

\section{References}

1. Humbert, M.; Galiè, N.; McLaughlin, V.V.; Rubin, L.J.; Simonneau, G. An insider view on the World Symposium on Pulmonary Hypertension. Lancet Respir. Med. 2019, 7, 484-485. [CrossRef]

2. Galiè, N.; Humbert, M.; Vachiéry, J.-L.; Gibbs, S.; Lang, I.M.; Kaminski, K.A.; Simonneau, G.; Peacock, A.; Noordegraaf, A.V.; Beghetti, M.; et al. 2015 ESC/ERS Guidelines for the diagnosis and treatment of pulmonary hypertension: The Joint Task Force for the Diagnosis and Treatment of Pulmonary Hypertension of the European Society of Cardiology (ESC) and the European Respiratory Society (ERS): Endorsed by: Association for European Paediatric and Congenital Cardiology (AEPC), International Society for Heart and Lung Transplantation (ISHLT). Eur. Heart J. 2015, 37, 67-119. [CrossRef]

3. Noordegraaf, A.V.; Chin, K.M.; Haddad, F.; Hassoun, P.M.; Hemnes, A.R.; Hopkins, S.R.; Kawut, S.M.; Langleben, D.; Lumens, J.; Naeije, R. Pathophysiology of the right ventricle and of the pulmonary circulation in pulmonary hypertension: An update. Eur. Respir. J. 2019, 53, 1801900. [CrossRef]

4. Humbert, M.; Guignabert, C.; Bonnet, S.; Dorfmüller, P.; Klinger, J.R.; Nicolls, M.R.; Olschewski, A.J.; Pullamsetti, S.S.; Schermuly, R.T.; Stenmark, K.R.; et al. Pathology and pathobiology of pulmonary hypertension: State of the art and research perspectives. Eur. Respir. J. 2019, 53, 1801887. [CrossRef] [PubMed]

5. De La Roque, E.D.; Smeralda, G.; Quignard, J.-F.; Freund-Michel, V.; Courtois, A.; Marthan, R.; Muller, B.; Guibert, C.; Dubois, M. Altered vasoreactivity in neonatal rats with pulmonary hypertension associated with bronchopulmonary dysplasia: Implication of both eNOS phosphorylation and calcium signaling. PLoS ONE 2017, 12, e0173044. [CrossRef] [PubMed]

6. Huertas, A.; Guignabert, C.; Barberà, J.A.; Bärtsch, P.; Bhattacharya, J.; Bhattacharya, S.; Bonsignore, M.R.; Dewachter, L.; Dinh-Xuan, A.T.; Dorfmüller, P.; et al. Pulmonary vascular endothelium: The orchestra conductor in respiratory diseases. Eur. Respir. J. 2018, 51, 1700745. [CrossRef] [PubMed]

7. Suresh, K.; Servinsky, L.; Jiang, H.; Bigham, Z.; Yun, X.; Kliment, C.; Huetsch, J.; Damarla, M.; Shimoda, L.A. Reactive oxygen species induced Ca2+ influx via TRPV4 and microvascular endothelial dysfunction in the SU5416/hypoxia model of pulmonary arterial hypertension. Am. J. Physiol. Cell. Mol. Physiol. 2018, 314, L893-L907. [CrossRef]

8. Rodat, L.; Savineau, J.-P.; Marthan, R.; Guibert, C. Effect of chronic hypoxia on voltage-independent calcium influx activated by 5-HT in rat intrapulmonary arteries. Pflügers Arch. Eur. J. Physiol. 2006, 454, 41-51. [CrossRef] [PubMed]

9. Chen, Y.; Yuan, T.; Zhang, H.; Yan, Y.; Wang, D.; Fang, L.; Lu, Y.; Du, G. Activation of Nrf2 Attenuates Pulmonary Vascular Remodeling via Inhibiting Endothelial-to-Mesenchymal Transition: An Insight from a Plant Polyphenol. Int. J. Biol. Sci. 2017, 13, 1067-1081. [CrossRef]

10. Tamura, Y.; Phan, C.; Tu, L.; Le Hiress, M.; Thuillet, R.; Jutant, E.-M.; Fadel, E.; Savale, L.; Huertas, A.; Humbert, M.; et al. Ectopic upregulation of membrane-bound IL6R drives vascular remodeling in pulmonary arterial hypertension. J. Clin. Investig. 2018, 128, 1956-1970. [CrossRef]

11. Pak, O.; Scheibe, S.; Esfandiary, A.; Gierhardt, M.; Sydykov, A.; Logan, A.; Fysikopoulos, A.; Veit, F.; Hecker, M.; Kroschel, F.; et al. Impact of the mitochondria-targeted antioxidant MitoQ on hypoxia-induced pulmonary hypertension. Eur. Respir. J. 2018, 51, 1701024. [CrossRef]

12. Song, T.; Zheng, Y.-M.; Wang, Y.-X. Cross Talk Between Mitochondrial Reactive Oxygen Species and Sarcoplasmic Reticulum Calcium in Pulmonary Arterial Smooth Muscle Cells. Adv. Exp. Med. Biol. 2017, 967, 289-298. [CrossRef]

13. Xu, D.; Li, Y.; Zhang, B.; Wang, Y.; Liu, Y.; Luo, Y.; Niu, W.; Dong, M.; Liu, M.; Dong, H.; et al. Resveratrol alleviate hypoxic pulmonary hypertension via anti-inflammation and anti-oxidant pathways in rats. Int. J. Med. Sci. 2016, 13, 942-954. [CrossRef] [PubMed]

14. Ng, P.C.; Hendry-Hofer, T.B.; Witeof, A.E.; Brenner, M.; Mahon, S.B.; Boss, G.R.; Haouzi, P.; Bebarta, V.S. Hydrogen Sulfide Toxicity: Mechanism of Action, Clinical Presentation, and Countermeasure Development. J. Med. Toxicol. 2019, 15, 287-294. [CrossRef] [PubMed]

15. Wang, R. Physiological Implications of Hydrogen Sulfide: A Whiff Exploration That Blossomed. Physiol. Rev. 2012, 92, 791-896. [CrossRef]

16. Wang, R.; Li, K.; Wang, H.; Jiao, H.; Wang, X.; Zhao, J.; Lin, H. Endogenous CSE/Hydrogen Sulfide System Regulates the Effects of Glucocorticoids and Insulin on Muscle Protein Synthesis. Oxidative Med. Cell. Longev. 2019, 2019, 1-15. [CrossRef] [PubMed]

17. Soriano, R.N.; Braga, S.P.; Breder, J.S.C.; Batalhao, M.E.; Oliveira-Pelegrin, G.R.; Ferreira, L.F.R.; Rocha, M.J.A.; Carnio, E.C.; Branco, L.G.S. Endogenous peripheral hydrogen sulfide is propyretic: Its permissive role in brown adipose tissue thermogenesis in rats. Exp. Physiol. 2018, 103, 397-407. [CrossRef] 
18. Kuo, M.M.; Kim, D.H.; Jandu, S.; Bergman, Y.; Tan, S.; Wang, H.; Pandey, D.R.; Abraham, T.P.; Shoukas, A.A.; Berkowitz, D.E.; et al. MPST but not CSE is the primary regulator of hydrogen sulfide production and function in the coronary artery. Am. $J$. Physiol. Circ. Physiol. 2016, 310, H71-H79. [CrossRef]

19. Singh, S.; Padovani, D.; Leslie, R.A.; Chiku, T.; Banerjee, R. Relative Contributions of Cystathionine $\beta$-Synthase and $\gamma-$ Cystathionase to $\mathrm{H}_{2} \mathrm{~S}$ Biogenesis via Alternative Trans-sulfuration Reactions. J. Biol. Chem. 2009, 284, 22457-22466. [CrossRef]

20. Kabil, O.; Vitvitsky, V.; Xie, P.; Banerjee, R. The Quantitative Significance of the Transsulfuration Enzymes for $\mathrm{H}_{2} \mathrm{~S}$ Production in Murine Tissues. Antioxid. Redox Signal. 2011, 15, 363-372. [CrossRef] [PubMed]

21. Kimura, H. Production and Physiological Effects of Hydrogen Sulfide. Antioxid. Redox Signal. 2014, 20, 783-793. [CrossRef] [PubMed]

22. Shibuya, N.; Mikami, Y.; Kimura, Y.; Nagahara, N.; Kimura, H. Vascular Endothelium Expresses 3-Mercaptopyruvate Sulfurtransferase and Produces Hydrogen Sulfide. J. Biochem. 2009, 146, 623-626. [CrossRef]

23. Shibuya, N.; Tanaka, M.; Yoshida, M.; Ogasawara, Y.; Togawa, T.; Ishii, K.; Kimura, H. 3-Mercaptopyruvate Sulfurtransferase Produces Hydrogen Sulfide and Bound Sulfane Sulfur in the Brain. Antioxid. Redox Signal. 2009, 11, 703-714. [CrossRef] [PubMed]

24. Mikami, Y.; Shibuya, N.; Kimura, Y.; Nagahara, N.; Ogasawara, Y.; Kimura, H. Thioredoxin and dihydrolipoic acid are required for 3-mercaptopyruvate sulfurtransferase to produce hydrogen sulfide. Biochem. J. 2011, 439, 479-485. [CrossRef] [PubMed]

25. Hosoki, R.; Matsuki, N.; Kimura, H. The Possible Role of Hydrogen Sulfide as an Endogenous Smooth Muscle Relaxant in Synergy with Nitric Oxide. Biochem. Biophys. Res. Commun. 1997, 237, 527-531. [CrossRef] [PubMed]

26. Li, L.; Whiteman, M.; Guan, Y.Y.; Neo, K.L.; Cheng, Y.; Lee, S.W.; Zhao, Y.; Baskar, R.; Tan, C.-H.; Moore, P.K. Characterization of a Novel, Water-Soluble Hydrogen Sulfide-Releasing Molecule (GYY4137). Circulation 2008, 117, 2351-2360. [CrossRef] [PubMed]

27. Zhao, W.; Zhang, J.; Lu, Y.; Wang, R. The vasorelaxant effect of $\mathrm{H}_{2} \mathrm{~S}$ as a novel endogenous gaseous KATP channel opener. EMBO J. 2001, 20, 6008-6016. [CrossRef]

28. Yang, G.; Wu, L.; Jiang, B.; Yang, W.; Qi, J.; Cao, K.; Meng, Q.; Mustafa, A.K.; Mu, W.; Zhang, S.; et al. H ${ }_{2} \mathrm{~S}$ as a Physiologic Vasorelaxant: Hypertension in Mice with Deletion of Cystathionine -Lyase. Science 2008, 322, 587-590. [CrossRef]

29. Sun, H.-J.; Wu, Z.-Y.; Nie, X.-W.; Bian, J.-S. Role of Endothelial Dysfunction in Cardiovascular Diseases: The Link Between Inflammation and Hydrogen Sulfide. Front. Pharmacol. 2020, 10, 1568. [CrossRef]

30. Xie, L.; Gu, Y.; Wen, M.; Zhao, S.; Wang, W.; Ma, Y.; Meng, G.; Han, Y.; Wang, Y.; Liu, G.; et al. Hydrogen Sulfide Induces Keap1 S-sulfhydration and Suppresses Diabetes-Accelerated Atherosclerosis via Nrf2 Activation. Diabetes 2016, 65, 3171-3184. [CrossRef]

31. Lin, Y.; Zeng, H.; Gao, L.; Gu, T.; Wang, C.; Zhang, H. Hydrogen Sulfide Attenuates Atherosclerosis in a Partially Ligated Carotid Artery Mouse model via Regulating Angiotensin Converting Enzyme 2 Expression. Front. Physiol. 2017, 8, 782. [CrossRef] [PubMed]

32. Peleli, M.; Bibli, S.-I.; Li, Z.; Chatzianastasiou, A.; Varela, A.; Katsouda, A.; Zukunft, S.; Bucci, M.; Vellecco, V.; Davos, C.H.; et al. Cardiovascular phenotype of mice lacking 3-mercaptopyruvate sulfurtransferase. Biochem. Pharmacol. 2020, 176, 113833. [CrossRef] [PubMed]

33. Abou-Hamdan, A.; Guedouari-Bounihi, H.; Lenoir, V.; Andriamihaja, M.; Blachier, F.; Bouillaud, F. Oxidation of $\mathrm{H}_{2} \mathrm{~S}$ in Mammalian Cells and Mitochondria. Methods Enzymol. 2015, 554, 201-228. [PubMed]

34. Zhang, D.; Wang, X.; Tian, X.; Zhang, L.; Yang, G.; Tao, Y.; Liang, C.; Li, K.; Yu, X.; Tang, X.; et al. The Increased Endogenous Sulfur Dioxide Acts as a Compensatory Mechanism for the Downregulated Endogenous Hydrogen Sulfide Pathway in the Endothelial Cell Inflammation. Front. Immunol. 2018, 9, 882. [CrossRef] [PubMed]

35. Chunyu, Z.; Junbao, D.; Dingfang, B.; Hui, Y.; Xiuying, T.; Chaoshu, T. The regulatory effect of hydrogen sulfide on hypoxic pulmonary hypertension in rats. Biochem. Biophys. Res. Commun. 2003, 302, 810-816. [CrossRef]

36. Yao, Z.; Wang, C. A Novel Mechanism of Sildenafil Improving the Excessive Proliferation and $\mathrm{H}_{2} \mathrm{~S}$ Production in Pulmonary Arterial Smooth Muscle Cells. J. Cardiovasc. Pharmacol. 2019, 74, 355-363. [CrossRef] [PubMed]

37. Zhang, D.; Wang, X.; Chen, S.; Chen, S.; Yu, W.; Liu, X.; Yang, G.; Tao, Y.; Tang, X.; Bu, D.; et al. Endogenous hydrogen sulfide sulfhydrates IKK $\beta$ at cysteine 179 to control pulmonary artery endothelial cell inflammation. Clin. Sci. 2019, 133, 2045-2059. [CrossRef] [PubMed]

38. Olson, K.R.; Dombkowski, R.A.; Russell, M.J.; Doellman, M.M.; Head, S.K.; Whitfield, N.L.; Madden, J.A. Hydrogen sulfide as an oxygen sensor/transducer in vertebrate hypoxic vasoconstriction and hypoxic vasodilation. J. Exp. Biol. 2006, 209, 4011-4023. [CrossRef]

39. Olson, K.R.; Whitfield, N.L.; Bearden, S.E.; Leger, J.S.; Nilson, E.; Gao, Y.; Madden, J.A. Hypoxic pulmonary vasodilation: A paradigm shift with a hydrogen sulfide mechanism. Am. J. Physiol. Integr. Comp. Physiol. 2010, 298, R51-R60. [CrossRef]

40. Yang, Y.; Zhang, B.; Liu, D.; Nie, W.; Yuan, J.; Wang, Z.; Guo, Y. Sodium hydrosulfide prevents hypoxia-induced pulmonary arterial hypertension in broilers. Br. Poult. Sci. 2012, 53, 608-615. [CrossRef]

41. Chen, Y.-H.; Wu, R.; Geng, B.; Qi, Y.-F.; Wang, P.-P.; Yao, W.-Z.; Tang, C.-S. Endogenous hydrogen sulfide reduces airway inflammation and remodeling in a rat model of asthma. Cytokine 2009, 45, 117-123. [CrossRef]

42. Sun, Y.; Tang, C.-S.; Jin, H.-F.; Du, J.-B. The vasorelaxing effect of hydrogen sulfide on isolated rat aortic rings versus pulmonary artery rings. Acta Pharmacol. Sin. 2011, 32, 456-464. [CrossRef] [PubMed]

43. Prieto-Lloret, J.; Shaifta, Y.; Ward, J.P.T.; Aaronson, P.I. Hypoxic pulmonary vasoconstriction in isolated rat pulmonary arteries is not inhibited by antagonists of $\mathrm{H}_{2}$ S-synthesizing pathways. J. Physiol. 2015, 593, 385-401. [CrossRef] [PubMed] 
44. Luo, L.; Liu, D.; Tang, C.; Du, J.; Liu, A.D.; Holmberg, L.; Jin, H. Sulfur dioxide upregulates the inhibited endogenous hydrogen sulfide pathway in rats with pulmonary hypertension induced by high pulmonary blood flow. Biochem. Biophys. Res. Commun. 2013, 433, 519-525. [CrossRef]

45. Madden, J.A.; Ahlf, S.B.; Dantuma, M.W.; Olson, K.R.; Roerig, D.L. Precursors and inhibitors of hydrogen sulfide synthesis affect acute hypoxic pulmonary vasoconstriction in the intact lung. J. Appl. Physiol. 2012, 112, 411-418. [CrossRef]

46. Olson, K.R.; Gao, Y.; DeLeon, E.R.; Markel, T.A.; Drucker, N.; Boone, D.; Whiteman, M.; Steiger, A.K.; Pluth, M.D.; Tessier, C.R.; et al. Extended hypoxia-mediated $\mathrm{H}_{2} \mathrm{~S}$ production provides for long-term oxygen sensing. Acta Physiol. 2020, 228 , e13368. [CrossRef] [PubMed]

47. Wang, Y.-F.; Mainali, P.; Tang, C.-S.; Shi, L.; Zhang, C.-Y.; Yan, H.; Liu, X.-Q.; Du, J.-B. Effects of nitric oxide and hydrogen sulfide on the relaxation of pulmonary arteries in rats. Chin. Med. J. 2008, 121, 420-423. [CrossRef] [PubMed]

48. Li, X.; Du, J.; Jin, H.; Geng, B.; Tang, C. Sodium hydrosulfide alleviates pulmonary artery collagen remodeling in rats with high pulmonary blood flow. Heart Vessel. 2008, 23, 409-419. [CrossRef]

49. Li, X.; Du, J.; Jin, H.; Tang, X.; Bu, D.; Tang, C. The regulatory effect of endogenous hydrogen sulfide on pulmonary vascular structure and gasotransmitters in rats with high pulmonary blood flow. Life Sci. 2007, 81, 841-849. [CrossRef] [PubMed]

50. Zhang, H.; Lin, Y.; Ma, Y.; Zhang, J.; Wang, C. Protective effect of hydrogen sulfide on monocrotaline-induced pulmonary arterial hypertension via inhibition of the endothelial mesenchymal transition. Int. J. Mol. Med. 2019, 44, 2091-2102. [CrossRef] [PubMed]

51. Wu, J.; Pan, W.; Wang, C.; Dong, H.; Xing, L.; Hou, J.; Fang, S.; Li, H.; Yang, F.; Yu, B. $\mathrm{H}_{2} \mathrm{~S}$ attenuates endoplasmic reticulum stress in hypoxia-induced pulmonary artery hypertension. Biosci. Rep. 2019, 39, 20190304. [CrossRef]

52. Vadivel, A.; Alphonse, R.S.; Ionescu, L.; Machado, D.S.; O’Reilly, M.; Eaton, F.; Haromy, A.; Michelakis, E.D.; Thébaud, B. Exogenous Hydrogen Sulfide $\left(\mathrm{H}_{2} \mathrm{~S}\right)$ Protects Alveolar Growth in Experimental O2-Induced Neonatal Lung Injury. PLoS ONE 2014, 9, e90965. [CrossRef] [PubMed]

53. Wei, H.-L.; Zhang, C.-Y.; Jin, H.-F.; Tang, C.-S.; Du, J.-B. Hydrogen sulfide regulates lung tissue-oxidized glutathione and total antioxidant capacity in hypoxic pulmonary hypertensive rats. Acta Pharmacol. Sin. 2008, 29, 670-676. [CrossRef] [PubMed]

54. Powell, C.R.; Dillon, K.M.; Matson, J.B. A review of hydrogen sulfide $\left(\mathrm{H}_{2} \mathrm{~S}\right)$ donors: Chemistry and potential therapeutic applications. Biochem. Pharmacol. 2018, 149, 110-123. [CrossRef]

55. Rose, P.; Dymock, B.W.; Moore, P.K. GYY4137, a Novel Water-Soluble, $\mathrm{H}_{2}$ S-Releasing Molecule. Methods Enzymol. 2015, 554, 143-167.

56. Zhang, H.; Hao, L.-Z.; Pan, J.-A.; Gao, Q.; Zhang, J.-F.; Kankala, R.K.; Wang, S.-B.; Chen, A.-Z. Microfluidic fabrication of inhalable large porous microspheres loaded with $\mathrm{H}_{2} \mathrm{~S}$-releasing aspirin derivative for pulmonary arterial hypertension therapy. J. Control. Release 2021, 329, 286-298. [CrossRef] [PubMed]

57. Fallon, M.B.; Abrams, G.A.; Abdel-Razek, T.T.; Dai, J.; Chen, S.-J.; Chen, Y.-F.; Luo, B.; Oparil, S.; Ku, D.D. Garlic prevents hypoxic pulmonary hypertension in rats. Am. J. Physiol. Cell. Mol. Physiol. 1998, 275, L283-L287. [CrossRef]

58. Benavides, G.A.; Squadrito, G.L.; Mills, R.W.; Patel, H.D.; Isbell, T.S.; Patel, R.P.; Darley-Usmar, V.M.; Doeller, J.E.; Kraus, D.W. Hydrogen sulfide mediates the vasoactivity of garlic. Proc. Natl. Acad. Sci. USA 2007, 104, 17977-17982. [CrossRef]

59. Yang, J.; Minkler, P.; Grove, D.; Wang, R.; Willard, B.; Dweik, R.; Hine, C. Non-enzymatic hydrogen sulfide production from cysteine in blood is catalyzed by iron and vitamin B6. Commun. Biol. 2019, 2, 1-14. [CrossRef]

60. Olson, K.R.; DeLeon, E.R.; Gao, Y.; Hurley, K.; Sadauskas, V.; Batz, C.; Stoy, G.F. Thiosulfate: A readily accessible source of hydrogen sulfide in oxygen sensing. Am. J. Physiol. Regul. Integr. Comp. Physiol. 2013, 305, R592-R603. [CrossRef] [PubMed]

61. Olson, K.R. $\mathrm{H}_{2} \mathrm{~S}$ and polysulfide metabolism: Conventional and unconventional pathways. Biochem. Pharmacol. 2018, 149, 77-90. [CrossRef] [PubMed]

62. Li, Q.; Lancaster, J.R. Chemical foundations of hydrogen sulfide biology. Nitric Oxide 2013, 35, 21-34. [CrossRef]

63. Furne, J.; Saeed, A.; Levitt, M.D. Whole tissue hydrogen sulfide concentrations are orders of magnitude lower than presently accepted values. Am. J. Physiol. Integr. Comp. Physiol. 2008, 295, R1479-R1485. [CrossRef]

64. Vitvitsky, V.; Kabil, O.; Banerjee, R. High Turnover Rates for Hydrogen Sulfide Allow for Rapid Regulation of Its Tissue Concentrations. Antioxid. Redox Signal. 2012, 17, 22-31. [CrossRef]

65. Libiad, M.; Vitvitsky, V.; Bostelaar, T.; Bak, D.W.; Lee, H.-J.; Sakamoto, N.; Fearon, E.; Lyssiotis, C.A.; Weerapana, E.; Banerjee, R. Hydrogen sulfide perturbs mitochondrial bioenergetics and triggers metabolic reprogramming in colon cells. J. Biol. Chem. 2019, 294, 12077-12090. [CrossRef] [PubMed]

66. Murphy, B.; Bhattacharya, R.; Mukherjee, P. Hydrogen sulfide signaling in mitochondria and disease. FASEB J. 2019, 33, 13098-13125. [CrossRef]

67. Cooper, C.E.; Brown, G.C. The inhibition of mitochondrial cytochrome oxidase by the gases carbon monoxide, nitric oxide, hydrogen cyanide and hydrogen sulfide: Chemical mechanism and physiological significance. J. Bioenerg. Biomembr. 2008, 40, 533-539. [CrossRef]

68. Saha, S.; Chakraborty, P.K.; Xiong, X.; Dwivedi, S.K.D.; Mustafi, S.B.; Leigh, N.R.; Ramchandran, R.; Mukherjee, P.; Bhattacharya, R. Cystathionine $\beta$-synthase regulates endothelial function via protein $S$-sulfhydration. FASEB J. 2016, 30, 441-456. [CrossRef]

69. Teng, H.; Wu, B.; Zhao, K.; Yang, G.; Wu, L.; Wang, R. Oxygen-sensitive mitochondrial accumulation of cystathionine -synthase mediated by Lon protease. Proc. Natl. Acad. Sci. USA 2013, 110, 12679-12684. [CrossRef] [PubMed]

70. Fu, M.; Zhang, W.; Wu, L.; Yang, G.; Li, H.; Wang, R. Hydrogen sulfide $\left(\mathrm{H}_{2} \mathrm{~S}\right)$ metabolism in mitochondria and its regulatory role in energy production. Proc. Natl. Acad. Sci. USA 2012, 109, 2943-2948. [CrossRef] 
71. Kabil, O.; Banerjee, R. Enzymology of $\mathrm{H}_{2} \mathrm{~S}$ Biogenesis, Decay and Signaling. Antioxid. Redox Signal. 2014, 20, 770-782. [CrossRef] [PubMed]

72. Mistry, R.K.; Murray, T.V.A.; Prysyazhna, O.; Martin, D.; Burgoyne, J.; Santos, C.; Eaton, P.; Shah, A.M.; Brewer, A.C. Transcriptional Regulation of Cystathionine- $\gamma$-Lyase in Endothelial Cells by NADPH Oxidase 4-Dependent Signaling. J. Biol. Chem. 2016, 291, 1774-1788. [CrossRef] [PubMed]

73. Dickhout, J.G.; Carlisle, R.E.; Jerome, D.E.; Mohammed-Ali, Z.; Jiang, H.; Yang, G.; Mani, S.; Garg, S.K.; Banerjee, R.; Kaufman, R.J.; et al. Integrated Stress Response Modulates Cellular Redox State via Induction of Cystathionine $\gamma$-Lyase. J. Biol. Chem. 2012, 287, 7603-7614. [CrossRef]

74. Wang, Y.; Wang, X.; Liang, X.; Wu, J.; Dong, S.; Li, H.; Jin, M.; Sun, D.; Zhang, W.; Zhong, X. Inhibition of hydrogen sulfide on the proliferation of vascular smooth muscle cells involved in the modulation of calcium sensing receptor in high homocysteine. Exp. Cell Res. 2016, 347, 184-191. [CrossRef]

75. Wang, Y.; Zhao, Z.; Shi, S.; Gao, F.; Wu, J.; Dong, S.; Zhang, W.; Liu, Y.; Zhong, X. Calcium sensing receptor initiating cystathioninegamma-lyase/hydrogen sulfide pathway to inhibit platelet activation in hyperhomocysteinemia rat. Exp. Cell Res. 2017, 358, 171-181. [CrossRef] [PubMed]

76. Sen, N.; Paul, B.D.; Gadalla, M.M.; Mustafa, A.K.; Sen, T.; Xu, R.; Kim, S.; Snyder, S.H. Hydrogen Sulfide-Linked Sulfhydration of NF-кB Mediates Its Antiapoptotic Actions. Mol. Cell 2012, 45, 13-24. [CrossRef] [PubMed]

77. Shibuya, N.; Koike, S.; Tanaka, M.; Ishigami-Yuasa, M.; Kimura, Y.; Ogasawara, Y.; Fukui, K.; Nagahara, N.; Kimura, H. A novel pathway for the production of hydrogen sulfide from D-cysteine in mammalian cells. Nat. Commun. 2013, 4, 1366. [CrossRef] [PubMed]

78. Kohl, J.B.; Mellis, A.-T.; Schwarz, G. Homeostatic impact of sulfite and hydrogen sulfide on cysteine catabolism. Br. J. Pharmacol. 2019, 176, 554-570. [CrossRef]

79. Kimura, H. Hydrogen sulfide: Its production and functions. Exp. Physiol. 2011, 96, 833-835. [CrossRef]

80. Módis, K.; Coletta, C.; Erdélyi, K.; Papapetropoulos, A.; Szabo, C. Intramitochondrial hydrogen sulfide production by 3mercaptopyruvate sulfurtransferase maintains mitochondrial electron flow and supports cellular bioenergetics. FASEB J. 2013, 27, 601-611. [CrossRef] [PubMed]

81. Huang, B.; Chen, C.-T.; Chen, C.-S.; Wang, Y.-M.; Hsieh, H.-J.; Wang, D.L. Laminar shear flow increases hydrogen sulfide and activates a nitric oxide producing signaling cascade in endothelial cells. Biochem. Biophys. Res. Commun. 2015, 464, 1254-1259. [CrossRef] [PubMed]

82. Nagahara, N. Multiple role of 3-mercaptopyruvate sulfurtransferase: Antioxidative function, $\mathrm{H}_{2} \mathrm{~S}$ and polysulfide production and possible SOxproduction. Br. J. Pharmacol. 2018, 175, 577-589. [CrossRef]

83. Paul, B.D.; Snyder, S.H.; Kashfi, K. Effects of hydrogen sulfide on mitochondrial function and cellular bioenergetics. Redox Biol. 2021, 38, 101772. [CrossRef]

84. Roman, H.B.; Hirschberger, L.L.; Krijt, J.; Valli, A.; Kožich, V.; Stipanuk, M.H. The Cysteine Dioxgenase Knockout Mouse: Altered Cysteine Metabolism in Nonhepatic Tissues Leads to Excess $\mathrm{H}_{2} \mathrm{~S} / \mathrm{HS}$-Production and Evidence of Pancreatic and Lung Toxicity. Antioxid. Redox Signal. 2013, 19, 1321-1336. [CrossRef]

85. Olson, K.R. Hydrogen Sulfide as an Oxygen Sensor. Antioxid. Redox Signal. 2015, 22, 377-397. [CrossRef] [PubMed]

86. Toombs, C.F.; Insko, M.A.; Wintner, E.A.; Deckwerth, T.L.; Usansky, H.; Jamil, K.; Goldstein, B.; Cooreman, M.; Szabo, C. Detection of exhaled hydrogen sulphide gas in healthy human volunteers during intravenous administration of sodium sulphide. Br. J. Clin. Pharmacol. 2010, 69, 626-636. [CrossRef] [PubMed]

87. Bazhanov, N.; Ansar, M.; Ivanciuc, T.; Garofalo, R.P.; Casola, A. Hydrogen Sulfide: A Novel Player in Airway Development, Pathophysiology of Respiratory Diseases, and Antiviral Defenses. Am. J. Respir. Cell Mol. Biol. 2017, 57, 403-410. [CrossRef]

88. Suzuki, Y.; Saito, J.; Munakata, M.; Shibata, Y. Hydrogen sulfide as a novel biomarker of asthma and chronic obstructive pulmonary disease. Allergol. Int. 2021, 70, 181-189. [CrossRef] [PubMed]

89. Stipanuk, M.H.; Ueki, I. Dealing with methionine/homocysteine sulfur: Cysteine metabolism to taurine and inorganic sulfur. J. Inherit. Metab. Dis. 2011, 34, 17-32. [CrossRef]

90. Madurga, A.; Golec, A.; Pozarska, A.; Ishii, I.; Mižíková, I.; Nardiello, C.; Vadász, I.; Herold, S.; Mayer, K.; Reichenberger, F.; et al. The $\mathrm{H}_{2} \mathrm{~S}$-generating enzymes cystathionine $\beta$-synthase and cystathionine $\gamma$-lyase play a role in vascular development during normal lung alveolarization. Am. J. Physiol. Cell. Mol. Physiol. 2015, 309, L710-L724. [CrossRef]

91. Wang, P.; Zhang, G.; Wondimu, T.; Ross, B.; Wang, R. Hydrogen sulfide and asthma. Exp. Physiol. 2011, 96, 847-852. [CrossRef] [PubMed]

92. Yanfei, W.; Lin, S.; Junbao, D.; Chaoshu, T. Impact of l-arginine on hydrogen sulfide/cystathionine- $\gamma$-lyase pathway in rats with high blood flow-induced pulmonary hypertension. Biochem. Biophys. Res. Commun. 2006, 345, 851-857. [CrossRef] [PubMed]

93. Xiaohui, L.; Junbao, D.; Lin, S.; Jian, L.; Xiuying, T.; Jianguang, Q.; Bing, W.; Hongfang, J.; Chaoshu, T. Down-Regulation of Endogenous Hydrogen Sulfide Pathway in Pulmonary Hypertension and Pulmonary Vascular Structural Remodeling Induced by High Pulmonary Blood Flow in Rats. Circ. J. 2005, 69, 1418-1424. [CrossRef]

94. Han, W.; Dong, Z.; Dimitropoulou, C.; Su, Y. Hydrogen Sulfide Ameliorates Tobacco Smoke-Induced Oxidative Stress and Emphysema in Mice. Antioxid. Redox Signal. 2011, 15, 2121-2134. [CrossRef] 
95. Asimakopoulou, A.; Panopoulos, P.; Chasapis, C.; Coletta, C.; Zhou, Z.; Cirino, G.; Giannis, A.; Szabo, C.; Spyroulias, G.A.; Papapetropoulos, A. Selectivity of commonly used pharmacological inhibitors for cystathionine $\beta$ synthase (CBS) and cystathionine $\gamma$ lyase (CSE). Br. J. Pharmacol. 2013, 169, 922-932. [CrossRef] [PubMed]

96. Du, S.-X.; Jin, H.-F.; Bu, D.-F.; Zhao, X.; Geng, B.; Tang, C.-S.; Du, J.-B. Endogenously generated sulfur dioxide and its vasorelaxant effect in rats1. Acta Pharmacol. Sin. 2008, 29, 923-930. [CrossRef]

97. Luo, L.; Chen, S.; Jin, H.; Tang, C.; Du, J. Endogenous generation of sulfur dioxide in rat tissues. Biochem. Biophys. Res. Commun. 2011, 415, 61-67. [CrossRef] [PubMed]

98. Huang, Y.; Shen, Z.; Chen, Q.; Huang, P.; Zhang, H.; Du, S.; Geng, B.; Zhang, C.; Li, K.; Tang, C.; et al. Endogenous sulfur dioxide alleviates collagen remodeling via inhibiting TGF- $\beta$ /Smad pathway in vascular smooth muscle cells. Sci. Rep. 2016, 6, 19503. [CrossRef]

99. Liu, J.; Yu, W.; Liu, Y.; Chen, S.; Huang, Y.; Li, X.; Liu, C.; Zhang, Y.; Li, Z.; Du, J.; et al. Mechanical stretching stimulates collagen synthesis via down-regulating SO2/AAT1 pathway. Sci. Rep. 2016, 6, 21112. [CrossRef] [PubMed]

100. Yu, W.; Liu, D.; Liang, C.; Ochs, T.; Chen, S.; Chen, S.; Du, S.; Tang, C.; Huang, Y.; Du, J.; et al. Sulfur Dioxide Protects Against Collagen Accumulation in Pulmonary Artery in Association with Downregulation of the Transforming Growth Factor $\beta 1 /$ Smad Pathway in Pulmonary Hypertensive Rats. J. Am. Heart Assoc. 2016, 5, e003910. [CrossRef] [PubMed]

101. Chen, B.; Nelin, V.E.; Locy, M.L.; Jin, Y.; Tipple, T.E. Thioredoxin-1 mediates hypoxia-induced pulmonary artery smooth muscle cell proliferation. Am. J. Physiol. Cell. Mol. Physiol. 2013, 305, L389-L395. [CrossRef]

102. Adesina, S.E.; Wade, B.E.; Bijli, K.M.; Kang, B.-Y.; Williams, C.R.; Ma, J.; Go, Y.-M.; Hart, C.M.; Sutliff, R.L. Hypoxia inhibits expression and function of mitochondrial thioredoxin 2 to promote pulmonary hypertension. Am. J. Physiol. Cell. Mol. Physiol. 2017, 312, L599-L608. [CrossRef]

103. Lignelli, E.; Palumbo, F.; Bayindir, S.G.; Nagahara, N.; Vadász, I.; Herold, S.; Seeger, W.; Morty, R.E. The $\mathrm{H}_{2}$ S-generating enzyme 3-mercaptopyruvate sulfurtransferase regulates pulmonary vascular smooth muscle cell migration and proliferation but does not impact normal or aberrant lung development. Nitric Oxide 2021, 107, 31-45. [CrossRef]

104. Tao, B.; Wang, R.; Sun, C.; Zhu, Y. 3-Mercaptopyruvate Sulfurtransferase, Not Cystathionine $\beta$-Synthase Nor Cystathionine $\gamma$-Lyase, Mediates Hypoxia-Induced Migration of Vascular Endothelial Cells. Front. Pharmacol. 2017, 8, 657. [CrossRef]

105. Smith, K.A.; Schumacker, P.T. Sensors and signals: The role of reactive oxygen species in hypoxic pulmonary vasoconstriction. J. Physiol. 2018, 597, 1033-1043. [CrossRef]

106. Leach, R.M.; Robertson, T.P.; Twort, C.H.; Ward, J.P. Hypoxic vasoconstriction in rat pulmonary and mesenteric arteries. Am. J. Physiol. Cell. Mol. Physiol. 1994, 266, L223-L231. [CrossRef]

107. Sommer, N.; Strielkov, I.; Pak, O.; Weissmann, N. Oxygen sensing and signal transduction in hypoxic pulmonary vasoconstriction. Eur. Respir. J. 2015, 47, 288-303. [CrossRef]

108. Prieto-Lloret, J.; Snetkov, V.A.; Shaifta, Y.; Docio, I.; Connolly, M.J.; Mackay, C.E.; Knock, G.A.; Ward, J.P.T.; Aaronson, P.I. Role of reactive oxygen species and sulfide-quinone oxoreductase in hydrogen sulfide-induced contraction of rat pulmonary arteries. Am. J. Physiol. Cell. Mol. Physiol. 2018, 314, L670-L685. [CrossRef]

109. Szijártó, I.A.; Markó, L.; Filipovic, M.R.; Miljkovic, J.L.; Tabeling, C.; Tsvetkov, D.; Wang, N.; Rabelo, L.A.; Witzenrath, M.; Diedrich, A.; et al. Cystathionine $\gamma$-Lyase-Produced Hydrogen Sulfide Controls Endothelial NO Bioavailability and Blood Pressure. Hypertension 2018, 71, 1210-1217. [CrossRef]

110. Connolly, M.J.; Prieto-Lloret, J.; Becker, S.; Ward, J.P.T.; Aaronson, P.I. Hypoxic pulmonary vasoconstriction in the absence of pretone: Essential role for intracellular $\mathrm{Ca}^{2+}$ release. J. Physiol. 2013, 591, 4473-4498. [CrossRef]

111. Ariyaratnam, P.; Loubani, M.; Morice, A.H. Hydrogen sulphide vasodilates human pulmonary arteries: A possible role in pulmonary hypertension? Microvasc. Res. 2013, 90, 135-137. [CrossRef]

112. Cui, T.; Liu, W.; Chen, S.; Yu, C.; Li, Y.; Zhang, J.-Y. Antihypertensive effects of allicin on spontaneously hypertensive rats via vasorelaxation and hydrogen sulfide mechanisms. Biomed. Pharmacother. 2020, 128, 110240. [CrossRef]

113. Kaye, A.D.; De Witt, B.J.; Anwar, M.; Smith, D.E.; Feng, C.J.; Kadowitz, P.J.; Nossaman, B.D. Analysis of responses of garlic derivatives in the pulmonary vascular bed of the rat. J. Appl. Physiol. 2000, 89, 353-358. [CrossRef]

114. Ku, D.D.; Abdel-Razek, T.T.; Dai, J.; Kim-Park, S.; Fallon, M.B.; Abrams, G.A. Garlic and its Active Metabolite Allicin Produce Endothelium- and Nitric Oxide-Dependent Relaxation In Rat Pulmonary Arteries. Clin. Exp. Pharmacol. Physiol. 2002, $29,84-91$. [CrossRef] [PubMed]

115. Kim-Park, S.; Ku, D.D. Garlic elicits a nitric oxide-dependent relaxation and inhibits hypoxic pulmonary vasoconstriction in rats. Clin. Exp. Pharmacol. Physiol. 2000, 27, 780-786. [CrossRef] [PubMed]

116. Mustafa, A.K.; Sikka, G.; Gazi, S.K.; Steppan, J.; Jung, S.M.; Bhunia, A.K.; Barodka, V.M.; Gazi, F.K.; Barrow, R.K.; Wang, R.; et al. Hydrogen Sulfide as Endothelium-Derived Hyperpolarizing Factor Sulfhydrates Potassium Channels. Circ. Res. 2011, 109, 1259-1268. [CrossRef] [PubMed]

117. Kiss, L.; Deitch, E.A.; Szabó, C. Hydrogen sulfide decreases adenosine triphosphate levels in aortic rings and leads to vasorelaxation via metabolic inhibition. Life Sci. 2008, 83, 589-594. [CrossRef]

118. Giuffrè, A.; Vicente, J.B. Hydrogen Sulfide Biochemistry and Interplay with Other Gaseous Mediators in Mammalian Physiology. Oxidative Med. Cell. Longev. 2018, 2018, 1-31. [CrossRef]

119. Dongó, E.; Beliczai-Marosi, G.; Dybvig, A.S.; Kiss, L. The mechanism of action and role of hydrogen sulfide in the control of vascular tone. Nitric Oxide 2018, 81, 75-87. [CrossRef] 
120. Sun, Y.; Huang, Y.; Yu, W.; Chen, S.; Yao, Q.; Zhang, C.; Bu, D.; Tang, C.; Du, J.; Jin, H. Sulfhydration-associated phosphodiesterase 5A dimerization mediates vasorelaxant effect of hydrogen sulfide. Oncotarget 2017, 8, 31888-31900. [CrossRef]

121. Kanagy, N.L.; Szabo, C.; Papapetropoulos, A. Vascular biology of hydrogen sulfide. Am. J. Physiol. Physiol. 2017, 312, C537-C549. [CrossRef] [PubMed]

122. Yang, Q.; He, G.-W. Imbalance of Homocysteine and $\mathrm{H}_{2} \mathrm{~S}$ : Significance, Mechanisms, and Therapeutic Promise in Vascular Injury. Oxidative Med. Cell. Longev. 2019, 2019, 1-11. [CrossRef] [PubMed]

123. Jain, S.K.; Micinski, D.; Lieblong, B.J.; Stapleton, T. Relationship between hydrogen sulfide levels and HDL-cholesterol, adiponectin, and potassium levels in the blood of healthy subjects. Atherosclerosis 2012, 225, 242-245. [CrossRef]

124. Peter, E.A.; Shen, X.; Shah, S.H.; Pardue, S.; Glawe, J.D.; Zhang, W.W.; Reddy, P.; Akkus, N.I.; Varma, J.; Kevil, C.G. Plasma Free $\mathrm{H}_{2} \mathrm{~S}$ Levels are Elevated in Patients with Cardiovascular Disease. J. Am. Heart Assoc. 2013, 2, e000387. [CrossRef]

125. Rajpal, S.; Katikaneni, P.; Deshotels, M.; Pardue, S.; Glawe, J.; Shen, X.; Akkus, N.; Modi, K.; Bhandari, R.; Dominic, P.; et al. Total sulfane sulfur bioavailability reflects ethnic and gender disparities in cardiovascular disease. Redox Biol. 2018, 15, 480-489. [CrossRef]

126. Sun, L.; Sun, S.; Li, Y.; Pan, W.; Xie, Y.; Wang, S.; Zhang, Z. Potential biomarkers predicting risk of pulmonary hypertension in congenital heart disease: The role of homocysteine and hydrogen sulfide. Chin. Med. J. 2014, 127, 893-899.

127. Sanli, C.; Oguz, D.; Olguntürk, R.; Tunaoglu, F.S.; Kula, S.; Pasaoglu, H.; Gulbahar, O.; Cevik, A. Elevated Homocysteine and Asymmetric Dimethyl Arginine Levels in Pulmonary Hypertension Associated with Congenital Heart Disease. Pediatr. Cardiol. 2012, 33, 1323-1331. [CrossRef]

128. Tan, Y.; Wang, S.; Ren, X.; Zhang, C.; Xu, F. The prognostic implications of perioperative endogenous hydrogen sulfide and nitric oxide levels in children with congenital heart disease complicated by pulmonary arterial hypertension. Eur. J. Nucl. Med. Mol. Imaging 2021, 180, 1915-1922. [CrossRef]

129. Seeger, W.; Adir, Y.; Barberà, J.A.; Champion, H.; Coghlan, J.G.; Cottin, V.; De Marco, T.; Galiè, N.; Ghio, S.; Gibbs, S.; et al. Pulmonary Hypertension in Chronic Lung Diseases. J. Am. Coll. Cardiol. 2013, 62, D109-D116. [CrossRef] [PubMed]

130. Chen, Y.-H.; Yao, W.-Z.; Geng, B.; Ding, Y.-L.; Lu, M.; Zhao, M.-W.; Tang, C.-S. Endogenous Hydrogen Sulfide in Patients With COPD. Chest 2005, 128, 3205-3211. [CrossRef] [PubMed]

131. Sun, Y.; Wang, K.; Li, M.-X.; He, W.; Chang, J.-R.; Liao, C.-C.; Lin, F.; Qi, Y.-F.; Wang, R.; Chen, Y.-H. Metabolic changes of $\mathrm{H}_{2} \mathrm{~S}$ in smokers and patients of COPD which might involve in inflammation, oxidative stress and steroid sensitivity. Sci. Rep. 2015, 5, 14971. [CrossRef]

132. Zhang, J.; Wang, X.; Chen, Y.; Yao, W.; Rosner, E.; Mastropietro, C.W. Exhaled Hydrogen Sulfide Predicts Airway Inflammation Phenotype in COPD. Respir. Care 2014, 60, 251-258. [CrossRef]

133. Morty, R.E. Recent advances in the pathogenesis of BPD. Semin. Perinatol. 2018, 42, 404-412. [CrossRef] [PubMed]

134. Kurata, H.; Ochiai, M.; Inoue, H.; Kusuda, T.; Fujiyoshi, J.; Ichiyama, M.; Wakata, Y.; Takada, H. Inflammation in the neonatal period and intrauterine growth restriction aggravate bronchopulmonary dysplasia. Pediatr. Neonatol. 2019, 60, 496-503. [CrossRef] [PubMed]

135. Donda, K.; Zambrano, R.; Moon, Y.; Percival, J.; Vaidya, R.; Dapaah-Siakwan, F.; Luo, S.; Duncan, M.R.; Bao, Y.; Wang, L.; et al. Riociguat prevents hyperoxia-induced lung injury and pulmonary hypertension in neonatal rats without effects on long bone growth. PLoS ONE 2018, 13, e0199927. [CrossRef]

136. Baker, C.D.; Alvira, C.M. Disrupted lung development and bronchopulmonary dysplasia: Opportunities for Lung Repair and Regeneration. Curr. Opin. Pediatr. 2014, 26, 306-314. [CrossRef]

137. Viña, J.; Vento, M.; García-Sala, F.; Puertes, I.R.; Gascó, E.; Sastre, J.; Asensi, M.; Pallardó, F.V. L-cysteine and glutathione metabolism are impaired in premature infants due to cystathionase deficiency. Am. J. Clin. Nutr. 1995, 61, 1067-1069. [CrossRef] [PubMed]

138. Zlotkin, S.H.; Anderson, G.H. The Development of Cystathionase Activity During the First Year of Life. Pediatr. Res. 1982, 16, 65-68. [CrossRef]

139. Sztuka, K.; Jasińska-Stroschein, M. Animal models of pulmonary arterial hypertension: A systematic review and meta-analysis of data from 6126 animals. Pharmacol. Res. 2017, 125, 201-214. [CrossRef]

140. Rosenberg, H.C.; Rabinovitch, M. Endothelial injury and vascular reactivity in monocrotaline pulmonary hypertension. Am. J. Physiol. Circ. Physiol. 1988, 255, H1484-H1491. [CrossRef]

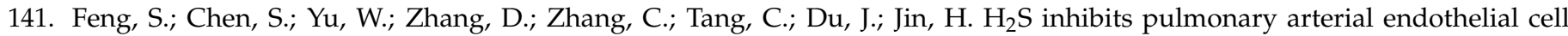
inflammation in rats with monocrotaline-induced pulmonary hypertension. Lab. Investig. 2017, 97, 268-278. [CrossRef] [PubMed]

142. Qingyou, Z.; Junbao, D.; Weijin, Z.; Hui, Y.; Chaoshu, T.; Chunyu, Z. Impact of hydrogen sulfide on carbon monoxide/heme oxygenase pathway in the pathogenesis of hypoxic pulmonary hypertension. Biochem. Biophys. Res. Commun. 2004, 317, 30-37. [CrossRef] [PubMed]

143. Hongfang, J.; Bailin, C.; Bin, Z.; Chunyu, Z.; Xinmin, L.; Weijin, Z.; Ying, S.; Chaoshu, T.; Junbao, D. Effects of hydrogen sulfide on hypoxic pulmonary vascular structural remodeling. Life Sci. 2006, 78, 1299-1309. [CrossRef]

144. López, V.; Moraga, F.A.; Llanos, A.J.; Ebensperger, G.; Taborda, M.I.; Uribe, E. Plasmatic Concentrations of ADMA and Homocystein in Llama (Lama glama) and Regulation of Arginase Type II: An Animal Resistent to the Development of Pulmonary Hypertension Induced by Hypoxia. Front. Physiol. 2018, 9, 606. [CrossRef] [PubMed] 
145. Li, W.; Jin, H.-F.; Liu, D.; Sun, J.-H.; Jian, P.-J.; Li, X.-H.; Tang, C.-S.; Du, J.-B. Hydrogen sulfide induces apoptosis of pulmonary artery smooth muscle cell in rats with pulmonary hypertension induced by high pulmonary blood flow. Chin. Med. J. 2009, 122, 3032-3038.

146. Yuan, S.; Yurdagul, A.; Peretik, J.M.; Alfaidi, M.; Al Yafeai, Z.; Pardue, S.; Kevil, C.G.; Orr, A.W.; Pearson, B.H. Cystathionine $\gamma$-Lyase Modulates Flow-Dependent Vascular Remodeling. Arter. Thromb. Vasc. Biol. 2018, 38, 2126-2136. [CrossRef]

147. Fan, J.; Fan, X.; Li, Y.; Ding, L.; Zheng, Q.; Guo, J.; Xia, D.; Xue, F.; Wang, Y.; Liu, S.; et al. Chronic Normobaric Hypoxia Induces Pulmonary Hypertension in Rats: Role of NF-кB. High Alt. Med. Biol. 2016, 17, 43-49. [CrossRef]

148. Hu, Y.; Feng, Z.; Feng, W.; Hu, T.; Guan, H.; Mao, Y. AOS ameliorates monocrotaline-induced pulmonary hypertension by restraining the activation of P-selectin/p38MAPK/NF-kB pathway in rats. Biomed. Pharmacother. 2019, 109, 1319-1326. [CrossRef]

149. Giustarini, D.; Del Soldato, P.; Sparatore, A.; Rossi, R. Modulation of thiol homeostasis induced by $\mathrm{H}_{2} \mathrm{~S}-$ releasing aspirin. Free. Radic. Biol. Med. 2010, 48, 1263-1272. [CrossRef]

150. Ding, H.-B.; Liu, K.-X.; Huang, J.-F.; Wu, D.-W.; Chen, J.-Y.; Chen, Q. Protective effect of exogenous hydrogen sulfide on pulmonary artery endothelial cells by suppressing endoplasmic reticulum stress in a rat model of chronic obstructive pulmonary disease. Biomed. Pharmacother. 2018, 105, 734-741. [CrossRef]

151. Pan, T.; Zhang, L.; Miao, K.; Wang, Y. A crucial role of endoplasmic reticulum stress in cellular responses during pulmonary arterial hypertension. Am. J. Transl. Res. 2020, 12, 1481-1490. [PubMed]

152. Rao, G.; Murphy, B.; Dey, A.; Dwivedi, S.K.D.; Zhang, Y.; Roy, R.V.; Chakraborty, P.; Bhattacharya, R.; Mukherjee, P. Cystathionine beta synthase regulates mitochondrial dynamics and function in endothelial cells. FASEB J. 2020, 34, 9372-9392. [CrossRef] [PubMed]

153. Madurga, A.; Mižíková, I.; Ruiz-Camp, J.; Vadász, I.; Herold, S.; Mayer, K.; Fehrenbach, H.; Seeger, W.; Morty, R.E. Systemic hydrogen sulfide administration partially restores normal alveolarization in an experimental animal model of bronchopulmonary dysplasia. Am. J. Physiol. Cell. Mol. Physiol. 2014, 306, L684-L697. [CrossRef]

154. Donnarumma, E.; Trivedi, R.K.; Lefer, D.J. Protective Actions of $\mathrm{H}_{2} \mathrm{~S}$ in Acute Myocardial Infarction and Heart Failure. In Comprehensive Physiology; Terjung, R., Ed.; John Wiley \& Sons: Hoboken, NJ, USA, 2017; pp. 583-602, ISBN 9780470650714.

155. Polhemus, D.J.; Li, Z.; Pattillo, C.B.; Gojon, G.; Giordano, T.; Krum, H. A Novel Hydrogen Sulfide Prodrug, SG 1002, Promotes Hydrogen Sulfide and Nitric Oxide Bioavailability in Heart Failure Patients. Cardiovasc. Ther. 2015, 33, 216-226. [CrossRef]

156. Kondo, K.; Bhushan, S.; King, A.L.; Prabhu, S.D.; Hamid, T.; Koenig, S.; Murohara, T.; Predmore, B.L.; Gojon, G.; Wang, R.; et al. $\mathrm{H}_{2} \mathrm{~S}$ Protects Against Pressure Overload-Induced Heart Failure via Upregulation of Endothelial Nitric Oxide Synthase. Circulation 2013, 127, 1116-1127. [CrossRef] [PubMed]

157. Tran, B.H.; Yu, Y.; Chang, L.; Tan, B.; Jia, W.; Xiong, Y.; Dai, T.; Zhong, R.; Zhang, W.; Le, V.M.; et al. A Novel Liposomal S-Propargyl-Cysteine: A Sustained Release of Hydrogen Sulfide Reducing Myocardial Fibrosis via TGF- $\beta 1 /$ Smad Pathway. Int. J. Nanomed. 2019, 14, 10061-10077. [CrossRef]

158. Culley, M.K.; Chan, S.Y. Mitochondrial metabolism in pulmonary hypertension: Beyond mountains there are mountains. J. Clin. Investig. 2018, 128, 3704-3715. [CrossRef] [PubMed]

159. Meng, G.; Liu, J.; Liu, S.; Song, Q.; Liu, L.; Xie, L.; Han, Y.; Ji, Y. Hydrogen sulfide pretreatment improves mitochondrial function in myocardial hypertrophy via a SIRT3-dependent manner. Br. J. Pharmacol. 2018, 175, 1126-1145. [CrossRef]

160. Zhang, J.; Yu, J.; Chen, Y.; Liu, L.; Xu, M.; Sun, L.; Luo, H.; Wang, Y.; Meng, G. Exogenous Hydrogen Sulfide Supplement Attenuates Isoproterenol-Induced Myocardial Hypertrophy in a Sirtuin 3-Dependent Manner. Oxidative Med. Cell. Longev. 2018, 2018, 1-17. [CrossRef]

161. Chakraborty, P.K.; Murphy, B.; Mustafi, S.B.; Dey, A.; Xiong, X.; Rao, G.; Naz, S.; Zhang, M.; Yang, D.; Dhanasekaran, D.N.; et al. Cystathionine $\beta$-synthase regulates mitochondrial morphogenesis in ovarian cancer. FASEB J. 2018, 32, 4145-4157. [CrossRef]

162. Quatredeniers, M.; Mendes-Ferreira, P.; Santos-Ribeiro, D.; Nakhleh, M.; Ghigna, M.-R.; Cohen-Kaminsky, S.; Perros, F. Iron Deficiency in Pulmonary Arterial Hypertension: A Deep Dive into the Mechanisms. Cells 2021, 10, 477. [CrossRef] [PubMed]

163. Ried, K. Garlic Lowers Blood Pressure in Hypertensive Individuals, Regulates Serum Cholesterol, and Stimulates Immunity: An Updated Meta-analysis and Review. J. Nutr. 2016, 146, 389S-396S. [CrossRef] [PubMed]

164. Wishart, D.S.; Feunang, Y.D.; Guo, A.C.; Lo, E.J.; Marcu, A.; Grant, J.R.; Sajed, T.; Johnson, D.; Li, C.; Sayeeda, Z.; et al. DrugBank 5.0: A Major Update to the DrugBank Database for 2018. Nucleic Acids Res. 2018, 46, D1074-D1082. [CrossRef]

165. Muzaffar, S.; Jeremy, J.Y.; Sparatore, A.; Del Soldato, P.; Angelini, G.D.; Shukla, N. H2 S-donating sildenafil (ACS6) inhibits superoxide formation and gp91phox expression in arterial endothelial cells: Role of protein kinases A and G. Br. J. Pharmacol. 2008, 155, 984-994. [CrossRef]

166. Verma, R.; Akhtar, Y.; Singh, S. A Review of Patents on Therapeutic Potential and Delivery of Hydroge n Sulfide. Recent Pat. Drug Deliv. Formul. 2017, 11, 114-123. [CrossRef] [PubMed] 